\title{
IMPLICIT REDEFINITIONS, EVIDENTIARY PROSCRIPTIONS, AND GUILTY MINDS: INTOXICATED WRONGDOERS AFTER MONTANA v. EGELHOFF
}

\author{
BRETT G. SWEITZER $†$
}

\begin{abstract}
You heard all about drugs. Sin ain't sin when good folks take a little pill, smoke a little marijuana. "I really didn't intend to kill that police officer." I don't buy that and I don't believe you do. A man doesn't take pills and take dope and drink whiskey and not be accountable for what he does. That's just an excuse.
\end{abstract}

-From the prosecutor's argument to the jury in Mississippi v. Lanier

\section{INTRODUCTION}

In July 1992, James Egelhoff was in northwestern Montana camping and picking mushrooms. ${ }^{2}$ He carried no personal items save the clothes he was wearing and a .38-caliber handgun. While camping, he met two other mushroom harvesters, Roberta Pavola and John Christianson. On July 12, Egelhoff, Pavola, and Christianson sold the mushrooms they had collected, bought some beer, and spent the day drinking at bars and a private party. Sometime after 9:00 P.M., the trio left the party and continued drinking while driving around in Christianson's car.

† B.A. 1993, Colgate University; J.D. Candidate 1998, University of Pennsylvania. Acknowledgments of helpful comments and overlooked errors are customary. As to the first, I thank my wife, Lisa Mathewson, for her many insightful comments, and the editors of the Law Review for their tireless efforts in putting this Comment in order. As to the second, I adopt the poet's modesty:

I washed thy face, but more defects I saw,

And rubbing off a spot still made a flaw.

I stretched thy joints to make thee even feet,

Yet still thou run'st more hobbling than is meet.

ANNE BRADSTREET, The Author to Her Book, in THE WORKS OF ANNE BRADSTREET 221, 221 (Jeannine Hensley ed., Belknap Press 1967) (1678).

See Lanier v. State, 533 So. 2d 473, 479 (Miss. 1988).

2 The factual details presented here are taken from the two appellate opinions in Egelhoff's case, that of the Supreme Court of Montana in State v. Egelhoff, 900 P.2d 260 (Mont. 1995), and that of the United States Supreme Court in Montana v. Egelhoff, 116 S. Ct. 2013 (1996). 
Shortly before midnight, sheriff's officers responded to reports of a car, later determined to be Christianson's, being driven erratically. The officers found Christianson's car in a ditch by the side of the road. The scene was macabre. Both Christianson and Pavola were dead, Christianson from a gunshot wound to the right back side of his head, and Pavola from a bullet through her left temple. The two bodies were in the front seat of the car. Egelhoff lay in the back of the car, alive, intoxicated, and yelling obscenities, with gunshot residue on his hands. On the floor in front of the driver's seat was Egelhoff's gun, containing four loaded rounds and two empty casings.

Egelhoff appeared severely intoxicated at the scene. He was largely incoherent, but repeatedly asked emergency personnel questions such as "Did you find him?" Egelhoff was taken to the hospital, where his blood-alcohol level was measured at .36\%. The next day, after Egelhoff sobered up, he remembered nothing about the previous evening; his last memory was of leaving the party sometime shortly before dusk. Egelhoff could not recall repeatedly asking authorities at the scene of the homicides "Did you find him?," nor could he recall to whom the "him" might refer. A medical doctor who examined Egelhoff at the hospital later testified at Egelhoff's trial that Egelhoff had probably suffered alcoholic "blackout."

Montana authorities charged Egelhoff with two counts of deliberate homicide, defined by Montana law as purposely or knowingly causing the death of another person. ${ }^{3}$ At trial, Egelhoff maintained that his extreme intoxication rendered him physically incapable of committing the homicides and accounted for his inability to remember that evening's events. Although Egelhoff was permitted to introduce evidence of his intoxication for these purposes, the jury was instructed, pursuant to Montana law, ${ }^{4}$ that it could not take Egelhoff's

${ }^{3}$ MONT. CODE ANN. § 45-5-102 (1997) provides:

(1) A person commits the offense of deliberate homicide if: (a) the person purposely or knowingly causes the death of another human being; or (b) the person attempts to commit, commits, or is legally accountable for the attempt or commission of robbery, sexual intercourse without consent, arson, burglary, kidnapping, aggravated kidnapping, felonious escape, felony assault, aggravated assault, or any other forcible felony and in the course of the forcible felony or flight thereafter, the person or any person legally accountable for the crime causes the death of another human being.

(2) A person convicted of the offense of deliberate homicide shall be punished by death as provided in 46-18-301 through 46-18-310, by life imprisonment, or by imprisonment in the state prison for a term of not less than 10 years or more than 100 years, except as provided in 46-18-219 and 46-18-222.

4 MONT. CODE ANN. § 45-2-203 (1997) provides: 
intoxication into account in determining whether he acted purposely or knowingly as required by Montana's definition of deliberate homicide. The jury found Egelhoff guilty on both counts. He was sentenced to eighty-four years in prison.

On appeal, Egelhoff claimed that the intoxication instruction deprived him of due process by removing from the jury's consideration a fact-his intoxication-relevant to a determination of his mental state, which was an element of deliberate homicide to be proven by the state beyond a reasonable doubt. A unanimous Supreme Court of Montana agreed, reversing Egelhoff's conviction and remanding the case for a new trial. ${ }^{5}$ The United States Supreme Court, without a majority opinion, reversed the decision of the Supreme Court of Montana and held that Montana's statutory prohibition of the use of in-1 toxication evidence to negate mens rea does not violate the Due Process Clause of the Fourteenth Amendment. ${ }^{6}$

Egelhoff's case sharply presents a persistent issue in criminal law: the bearing, if any, of voluntary intoxication on criminal liability. A thorough examination of this issue must address two related questions. First, does holding severely intoxicated wrongdoers ${ }^{7}$ criminally liable to the same extent as sober offenders violate due process? Put more precisely, does substantive due process ${ }^{8}$ require that, at some

A person who is in an intoxicated condition is criminally responsible for his conduct and an intoxicated condition is not a defense to any offense and may not be taken into consideration in determining the existence of a mental state which is an element of the offense unless the defendant proves that he did not know that it was an intoxicating substance when he consumed, smoked, sniffed, injected, or otherwise ingested the substance causing the condition.

${ }^{5}$ See Egelhoff, 900 P.2d at 266. Two justices dissented in part on the separate issue of retroactive applicability. See id. at 269 (Trieweiler, J., specially concurring in part and dissenting in part).

${ }^{6}$ See Egelhoff, 116 S. Ct. at 2024 (plurality opinion). Unless specifically noted otherwise, all citations to the U.S. Supreme Court's Egelhoff decision are to the plurality opinion.

"I use "wrongdoer" here instead of "offender" to avoid begging the question of criminal liability. To refer to intoxicated wrongdoers as offenders assumes that such individuals are, in fact, guilty of the offense, when the point is precisely that some intoxicated wrongdoers may not possess the requisite mens rea to be guilty, even though the actus reus element clearly is satisfied. I will use "intoxicated wrongdoer," then, to refer to a defendant who causes the harm proscribed by the law, but might not have possessed the requisite mens rea to be guilty of the offense.

${ }^{8}$ This Comment does not consider the official propriety of substantive due process review. Although the Supreme Court has often questioned such review, see, e.g., Kansas v. Hendricks, 117 S. Ct. 2072 (1997) (using scare quotes when speaking of substantive due process review); West Coast Hotel Co. v. Parrish, 300 U.S. 379 (1937) 
theoretical point when an intoxicated wrongdoer's drunkenness precludes a finding of mens rea, he not be held criminally liable to the same extent as a sober offender who causes the same harm?

Second, if society may-consistent with substantive due processchoose to treat intoxicated wrongdoers and sober offenders alike, does procedural due process nonetheless limit the way in which such a social judgment may be effectuated? These are the two questions addressed in this Comment.

In order to set and address these questions effectively, the Comment is divided into five Parts. Part I clarifies two basic distinctions that limit the scope of the Comment: the common law distinction between voluntary and involuntary intoxication, and the distinction between intoxication asserted by a defendant as an affirmative defense and as a failure of proof claim. Part II reviews the current status of state law on the issue of voluntary intoxication's bearing on criminal liability and identifies the current trend toward equal treatment of intoxicated wrongdoers and sober offenders, demonstrating the importance of the issues raised in this Comment.

Part III addresses directly the two principal issues: the substantive and procedural due process limitations on the criminal liability of intoxicated wrongdoers. This Part clarifies the Supreme Court's holding in Egelhoff, critically examines the Court's reasoning, and poses some objections to the statutory scheme at issue in that case. Here I will argue that (1) the culpability requirement of the criminal law demands that some severely intoxicated wrongdoers be treated differently than sober offenders; and (2) even if intoxicated wrongdoers and sober offenders may be treated alike, procedural due process requires that this be effectuated through the substantive criminal law rather than through limiting defendants' ability to present intoxication evidence to rebut the state's prima facie case of criminal liability.

Part IV explores the implications of the Supreme Court's ruling in Egelhoff for other states' exclusions of voluntary intoxication evidence. Here I examine how other states' exclusionary schemes bear on the objections to Montana's scheme that were raised in Part III. Part V suggests a different approach to the treatment of intoxicated

(eschewing Lochnerera substantive due process protection of economic rights), even the Court's most skeptical Justices have recognized and employed substantive due process review. See Washington v. Glucksberg, 117 S. Ct. 2258, 2267 (1997) (Rehnquist, C.J.) ("The Due Process Clause guarantees more than fair process.... The Clause also provides heightened protection against government interference with certain fundamental rights and liberty interests."). 
wrongdoers. Specifically, this Part briefly outlines an offense of intoxicated criminal conduct, and demonstrates how this approach avoids the due process objections to the exclusionary schemes discussed in Parts III and IV.

\section{Two Basic DISTINCTIONS}

Two basic distinctions must be made clear from the outset. First, the common law traditionally has distinguished voluntary intoxication from involuntary intoxication..$^{9}$ Generally, more exculpatory weight is given to evidence of involuntary intoxication because an involuntarily intoxicated wrongdoer typically is viewed as morally less culpable than a voluntarily intoxicated wrongdoer. ${ }^{10}$ This Comment, is concerned only with claims of voluntary intoxication, which make up the overwhelming majority of intoxication-related claims raised by criminal defendants. A state's treatment of involuntary intoxication is not completely irrelevant to the arguments presented below, ${ }^{11}$ but it will not be a focus of the discussion. I will therefore use "intoxication" to mean voluntary intoxication.

Second, there are two fundamental ways in which intoxication evidence might be presented to mitigate a wrongdoer's criminal liability: as an affirmative defense and as a failure of proof claim. Intoxication has almost never been recognized as an affirmative defense, ${ }^{12}$ although this has changed to some degree with the

${ }^{9}$ Intoxication is generally held to be involuntary if it (1) is coerced; (2) occurs by innocent mistake; (3) results unexpectedly from prescribed medication; or (4) causes a temporary psychotic reaction due to the existence of a pre-disposing mental or physical condition of which the person is unaware. See, e.g., City of Minneapolis v. Altimus, 238 N.W.2d 851, 856 (Minn. 1976). Claims of involuntary intoxication are rare. See, e.g., R.U. Singh, History of the Defence of Drunkenness in English Criminal Law, 49 LAW Q. REV. 528, $545 \mathrm{n} .81$ (1933) ("There is no English case where the defence of involuntary drunkenness was urged or discussed. The only case where reference is found to it is Pearson's Case.").

${ }^{10}$ See, e.g., Pearson's Case, 168 Eng. Rep. 1108, 1108 (Carlisle Sp. Assizes 1835) ("If a party be made drunk by stratagem, or the fraud of another, he is not responsible."); 1 SIR MATTHEW HALE, THE HISTORY OF THE PleAs OF THE CROWN 32 (London, Sollom Emlyn 1680) ("[I]f a person by the unskilfulness of his physician, or by the contrivance of his enemies, eat[s] or drink[s] such a thing as causeth such a temporary or permanent phrenzy... this puts him into the same condition, in reference to crimes, as any other phrenzy and equally excuseth him.").

"See infra note 146 and accompanying text.

12 The common law did not clearly delineate affirmative defenses from failure of proof claims, but it is clear that intoxication, to the extent it could exculpate, was thought to affect the offender's intent. See, e.g., United States v. Roudenbush, 27 F. Cas. 902, 904 (C.C.E.D. Pa. 1832) (No. 16,198) ("Intoxication is no excuse for crime, 
promulgation of the Model Penal Code. ${ }^{13}$ The other potential use of intoxication evidence is to attack the State's prima facie case by negating (i.e., establishing a reasonable doubt as to the proof of) an element of the offense charged. Although this use is often referred to as a "defense," and is in a general sense a defense to criminal liability, it is properly termed a failure of proof claim.

At common law, intoxication evidence was relevant to negate only the mens rea element of specific intent crimes; the actus reus element could not be negated, due to the common law fiction that the voluntariness of the consumption of the intoxicant "substituted" for the voluntariness of the offense's actus reus element. ${ }^{14}$

The distinction between employing intoxication as an affirmative defense and using it to support a claim that the State has failed to prove mens rea is critically important, because these two uses of intoxication evidence implicate due process to a different extent. In a criminal prosecution, the State bears the burden of proving every element of an offense beyond a reasonable doubt. ${ }^{15}$ In contrast, a state may place the burden of persuasion regarding affirmative defenses upon the defendant. ${ }^{16}$ A state, therefore, must bear the burden of disproving beyond a reasonable doubt a defendant's intoxicationbased failure of proof claim, whereas the defendant may be required to bear the burden of persuasion regarding an affirmative defense of intoxication, if such a defense exists under state law.

when the offence consists merely in doing a criminal act, without regarding intention. But when the act done is innocent in itself, and criminal only when done with a corrupt or malicious motive, a jury may, from intoxication, presume that there was a want of criminal intention....").

${ }^{13}$ See MODEL PENAL CODE $\$ 2.08(4)$ (Proposed Official Draft 1962), discussed infra Part II.B.

${ }^{14}$ At its logical extreme, this doctrine has supported the convictions of intoxicated wrongdoers who were legally unconscious at the time of their offensive conduct. See, e.g., People v. Velez, 221 Cal. Rptr. 631, 637 (Ct. App. 1985) ("Clearly, then, one who becomes voluntarily intoxicated to the point of unconsciousness can have no actual intent to commit a crime; rather, criminal responsibility is justified on the theory that having chosen to breach one's duty to others of acting with reason and conscience, one may not entirely avoid criminal harm caused by one's breach of duty.").

${ }^{15}$ See In re Winship, 397 U.S. 358, 364 (1970) ("[T] he Due Process Clause protects the accused against conviction except upon proof beyond a reasonable doubt of every fact necessary to constitute the crime with which he is charged.").

${ }^{16}$ See Patterson v. New York, 432 U.S. 197, 210 (1977) ("We ... decline to adopt as a constitutional imperative, operative countrywide, that a State must disprove beyond a reasonable doubt every fact constituting any and all affirmative defenses related to the culpability of an accused."). 
This Comment is concerned only with the use of intoxication evidence to support a failure of proof claim as to the mens rea element of a criminal offense. Therefore, the nature and extent of the State's due process burden to prove mens rea beyond a reasonable doubt is of central concern.

\section{CURRENT LAW AND ITS GENESIS}

\section{A. Intoxication Under the Common Law}

At early common law, a wrongdoer's intoxication, usually but not necessarily by way of alcohol, had no effect on his criminal liability; intoxication neither aggravated nor mitigated the underlying offense. ${ }^{17}$ During the nineteenth century, however, a change in the sig-

${ }^{17}$ Some early common law authorities claim that intoxication in fact aggravated the underlying offense. See, e.g., Beverley's Case, 76 Eng. Rep. 1118, 1123 (K.B. 1603) ( $[D]$ runkenness does not extenuate his act ... nor turn to his avail: but it is a great offence in itself, and therefore aggravates his offence, and doth not derogate from the act which he did during that time."); Reniger v. Fogossa, 75 Eng. Rep. 1, 31 (Ex. Ch. 1551) (" $[T]$ hat such a man [who has killed while drunk] deserves double punishment, because he has doubly offended, viz. in being drunk to the evil example of others, and in committing the crime of homicide."); 4 WILIIAM BLACKSTONE, COMMENTARIES *2526 (" $[\mathrm{A}] \mathrm{s}$ to artificial, voluntarily contracted madness, by drunkenness or intoxication ... our law looks upon this as an aggravation of the offence, rather than as an excuse for any criminal misbehavior.").

Twentieth century commentators suggest that these authorities indicate that intoxication may have, at most, led to a greater sentence at common law, not that an intoxicated wrongdoer was charged with a more serious crime. See David McCord, The English and American History of Voluntary Intoxication to Negate Mens Rea, $11 \mathrm{~J}$. LEGAL HIST. 372, 374 (1990) (discussing Fogossa and Beverley's Case and concluding that references to aggravation "[do] not mean that the crime could be raised to a higher grade of offense, since there were no higher grades of offenses based on the actor's being intoxicated"); Singh, supra note 9, at 532 (concluding that reference to intoxication as aggravating an underlying offense "was little more than rhetorical flourish inspired by the spirit of the times").

In the United States, the first reported case on the issue held that intoxication had no effect on criminal liability. See Res Publica v. Weidle, 2 Dall. 88, 91 (Pa. 1781) ("[D]runkenness is no justification, or excuse, for committing the offence."); see also McCord, supra, at 375 ("[T]he earliest American authority stands for the proposition that intoxication does not affect culpability."). Subsequent American cases confirmed this view. See, e.g., McIntyre v. People, 38 Ill. 514, 520 (1865) ("That [drunkenness] is no excuse is certainly true, but that it should be held in law to aggravate crime is not, we conceive, a correct proposition.").

Other English common law authorities support this latter view. See, e.g., MICHAEL DALTON, THE COUNTRY JUSTICE 299 (London, William Rawlins \& Samuel Roycroft 1690) ("[I]f a man that is drunk, killeth another, that is felony of death; for it is a voluntary ignorance in him."); HALE, supra note 10, at 32 (noting that a person committing homicide while drunk "shall have no privilege by this voluntary contracted madness, but shall have the same judgment as if he were in his right senses"); 1 RICHARD 
nificance given a wrongdoer's intoxication was brought about by two competing concerns: the emerging judgment that some intoxicated wrongdoers may not be as morally culpable as sober offenders, and the continuing belief that voluntarily intoxicated wrongdoers should not totally escape the consequences of their harmful conduct. These concerns, together with new pharmacological theories about intoxication, brought about a reconceptualization of offenses into two categories: "specific intent" crimes and "general intent" crimes. ${ }^{18}$ Using these labels, common law courts developed the rule that voluntary intoxication could negate the mens rea element of specific intent crimes, but not of general intent crimes. ${ }^{19}$ This approach resulted from a general amelioration of the harsh English common law (which provided for capital punishment for a wide variety of offenses), checked by courts' refusal to allow intoxication to mitigate second degree murder to manslaughter. ${ }^{20}$ The specific intent/general intent distinction was embraced by nearly all American jurisdictions by the

HOOKER, OF THE LAWS OF THE ECCLESIASTICAL POLITY 186 (J.M. Dent \& Sons Ltd. 1965) (1593) ("It is no excuse therefore unto him, who being drunk ... allegeth that his wits were not his own.").

${ }^{18}$ See People v. Hood, 462 P.2d 370, 377-78 (Cal. 1969) (discussing the common law development of specific intent and general intent crimes); McCord, supra note 17, at 379-82. Although the distinction between specific and general intent crimes is notoriously vague, the common law courts developing these categories defined general intent crimes as those crimes that require only the intention to do the actus reus of the crime and defined specific intent crimes as those crimes that require some further intention in addition to the intention to do the actus reus of the crime. See Hood, 462 P.2d at 378; see also JOSHUA DRESSLER, UNDERSTANDING CRIMINAL LAW $\$ 10.06$ (2d ed. 1995).

${ }_{19}$ See, e.g., Director of Pub. Prosecutions v. Majewski, 2 All E.R. 142, 149 (Eng. H.L. 1976) (stating that case law from 1920 onward has made it clear that "it is only in the limited class of cases requiring proof of specific intent that drunkeness can exculpate").

${ }^{20}$ See Hood, 462 P.2d at 377-78; McCord, supra note 17, at 379-81 (discussing Pirtle v. State, 28 Tenn. (9 Hum.) 663 (1849), the first American case in which a court distinguished between intoxication's exculpatory effect on second-degree murder versus manslaughter). Later courts relied on this distinction to develop the specific intent/general intent dichotomy and distinguish intoxication's exculpatory effect on the two classes of crimes. See, e.g., State v. Johnson, 41 Conn. 584 (1874). 
mid-twentieth century, ${ }^{21}$ and continues to define the exculpatory effect of intoxication in twenty-two states today. ${ }^{22}$

\section{B. Other Contemporary Approaches to Intoxication}

The promulgation of the Model Penal Code ("MPC") by the American Law Institute in 1962 marked the first uniform shift in the exculpatory effect given voluntary intoxication. Eschewing the common law's specific intent/general intent dichotomy, the drafters of the MPC gave intoxication evidence its full logical exculpatory effect by allowing it to negate the mens rea element of all offenses, ${ }^{23}$ except for offenses requiring the mens rea of recklessness. ${ }^{24}$ Also, for the first time, the MPC recognized pathological intoxication ${ }^{25}$ as an affirmative defense, but only if the defendant's consequent incapacity

${ }^{21}$ Three states resisted moving to the specific intent/general intent approach, retaining the original common law approach instead. See Choice v. State, 31 Ga. 424 (1860) (codified at GA. CODE ANN. § 16-3-4 (1996)); Schaller v. State, 14 Mo. 502 (1851) (codified at MO. REv. STAT. $\$ 562.076$ (Supp. 1997)); Harris v. State, 169 S.W. 657 (Tex. Crim. App. 1914) (codified at TEx. PENAL CodE ANN. $\$ 8.04$ (West 1994)).

${ }^{22}$ See CAL. PENAL CODE § 22(B) (West 1995); COLO. REV. STAT. § 18-1-804(1) (1986); 720 ILL. COMP. STAT. ANN. 5/6-3 (a) (West 1993); IOWA CODE $§ 701.5$ (1993); KAN. STAT. ANN. § 21-3208(2) (1995); LA. REV. STAT. ANN. § 14:15(2) (West 1997); MINN. STAT. § 609.075 (1994); NEV. REV. STAT. § 193.220 (1997); S.D. CoDIFIED LAWS § 22-5-5 (Michie 1988); WASH. REV. CODE ANN. § 9A.16.090 (West 1988); WYO. STAT. ANN. § 6-1-202(a) (Michie 1988); Gardner v. State, 480 So. 2d 91 (Fla. 1985); Shell v. State, 512 A.2d 358 (Md. 1986); Commonwealth v. Henson, 476 N.E.2d 947 (Mass. 1985); People v. Savoie, 349 N.W.2d 139 (Mich. 1984); State v. Cain, 393 N.W.2d 727 (Neb. 1986); State v. Brown, 931 P.2d 69, $74-75$ (N.M. 1996); State v. Kirkley, 302 S.E.2d 144 (N.C. 1983), overruled on other grounds by State v. Shank, 367 S.E.2d 639 (N.C. 1988); State v. Fox, 428 N.E.2d 410 (Ohio 1981); Edwards v. State, 655 P.2d 1048 (Okla. Crim. App. 1982); State v. Doyon, 416 A.2d 130 (R.I. 1980); State v. Keeton, 272 S.E.2d 817 (W. Va. 1980).

${ }^{23}$ See MODEL PENAL CODE $\$ 2.08 \mathrm{cmt} .1$ (Proposed Official Draft 1962) ("If the mental state which is the basis of the law's concern does not exist, the reason for its nonexistence is quite plainly immaterial.").

${ }^{24}$ See id. $\$ 2.08$. This hedging evidences the drafters' concerns about the moral culpability of intoxicated wrongdoers and their conflicting concerns about the need to punish those wrongdoers, the two competing concerns that originally motivated common law courts to develop the specific intent/general intent dichotomy.

${ }^{25}$ The MPC defines "pathological intoxication" as "intoxication grossly excessive in degree, given the amount of the intoxicant, to which the actor does not know he is susceptible." MODEL PENAL CODE $§ 2.08(5)$ (c) (1985). 
rose to the level of insanity as defined in the MPC. ${ }^{26}$ Presently, fourteen states follow some version of the MPC approach. ${ }^{27}$

Despite the influence of the MPC, a second shift in the treatment of intoxicated wrongdoers has occurred in recent years. This shift harks back to the original common law approach, whereby intoxication was excluded altogether from the mens rea inquiry and made irrelevant to an offender's criminal liability. ${ }^{28}$ Only three states have continuously followed this exclusionary approach, ${ }^{29}$ but nine more have recently joined their ranks, and eight others are considering a similar change. ${ }^{30}$ In addition, two states limit the exculpatory effect of intoxication to the negation of the premeditation element of first-degree murder. ${ }^{\text {s! }}$

${ }^{26}$ See MODEL PENAL CODE $\$ 2.08$ (4) (Proposed Official Draft 1962). Prior to the promulgation of the MPC, intoxication "defenses" took the form of failure of proof claims. See supra Part I.

${ }^{27}$ See ALA. CODE $\S 13 A-3-2$ (1996); ALASKA STAT. $\$ 11.81 .630$ (Michie 1996); CONN. GEN. STAT. ANN. § 53a-7 (West 1994); KY. REV. STAT. ANN. § 501.080 (Michie 1995); ME. REV. STAT. ANN. tit. 17A, § 37 (West 1983); N.H. REV. STAT. ANN. § 626:4 (1996); N.J. Rev. STAT. § 2C:2-8 (1995); N.Y. PENAL LAW § 15.25 (McKinney 1987); N.D. CENT. CODE § 12.1-04-02 (1989); OR. REV. STAT. § 161.125 (1994); TENN. CODE ANN. § 39-11503 (1983); UTAH CODE ANN. § 76-2-306 (1993); WIS. STAT. § 939.42 (1993); State v. Galvin, 514 A.2d 705 (Vt. 1986).

${ }^{28}$ See supra note 17.

${ }^{29}$ See supra note 21.

so In addition to Georgia, Missouri, and Texas, nine states have returned to the original common law approach. See ARIZ. REV. STAT. ANN. \$ 13-503 (West Supp. 1996) (previously an MPC state); ARK. CODE ANN. \$ 5-2-207 (Michie 1993) (previously a specific intent/general intent state); DEL. CODE ANN. tit. 11, $\$ 421$ (1995) (previously a specific intent/general intent state); HAW. REV. STAT. $\S 702-230$ (Supp. 1992) (previously an MPC state); IDAHO CODE § 18-116 (Supp. 1997) (previously a specific intent/general intent state); IND. CODE ANN. \$§ 35-41-2-5, -3-5 (West Supp. 1997) (previously allowing intoxication to negate the mens rea element of all crimes); MONT. CODE ANN. § 45-2-203 (1997) (previously an MPC state); Lanier v. State, 533 So. 2d 473 (Miss. 1988) (previously a specific intent/general intent state); State v. Vaughn, 232 S.E.2d 328 (S.C. 1977) (previously a specific intent/general intent state).

Eight more states currently are considering a return to the original common law approach. See S.B. 579, 1997-1998 Reg. Sess. (Cal. 1997); S.B. 168, 15th Leg., 1st Reg. Sess. (Fla. 1997); H.B. 2310, 77th Leg., 1997 Reg. Sess. (Kan. 1997); S.B. 339, 69th Reg. Sess. (Nev. 1997); H.B. 1009, 43d Leg., 1st Reg. Sess. (N.M. 1997); H.B. 2441, 69th Leg., 1997 Reg. Sess. (Or. 1997); S.B. 857, 1997-1998 Reg. Sess. (Pa. 1997); H.B. 1672, 55th Leg., 1997 Reg. Sess. (Wash. 1997).

${ }^{31}$ See 18 PA. CONS. STAT. ANN. $\$ 308$ (West 1994); Gills v. Commonwealth, 126 S.E. 51 (Va. 1925) ("[W]here a party is charged with murder, if it appear that the accused was too drunk to be capable of deliberating and premeditating, then he can be convicted only of murder in the second degree."). But see S.B. 1120, 1995-1996 Reg. Sess. (Pa. 1995) (providing for repeal of Pennsylvania's murder exception). 
The motivation behind this recent resurgence of the original common law approach is difficult to isolate. The familiar supporting arguments of deterrence, incapacitation, and simple retribution are long-standing. ${ }^{32}$ One possible explanation is that a general trend toward recognition of "victims' rights" is motivating state legislatures to curb the exculpatory effect of intoxication. ${ }^{33}$ Regardless of the reasons for the new-found popularity of the original common law approach, an increasing number of states are legislating it.

\section{THE DUE PROCESS INQUIRY}

\section{A. Questions Raised by the Current Trend Toward Denying Intoxication Any Exculpatory Effect}

The recent trend toward treating intoxication as irrelevant to criminal liability raises two important sets of questions. First, does it violate substantive due process to hold severely intoxicated wrongdoers criminally liable to the same extent as sober offenders? I refer to this as the criminalization question because it asks whether a state may, consistent with substantive due process, redefine the elements of crimes so as to render intoxication evidence irrelevant to criminal liability.

Second, if the criminalization decision does not violate substantive due process, does procedural due process nonetheless require that the criminalization judgment be embodied in a state's substantive law, rather than in an evidentiary proscription? I refer to this as the procedural question because it asks whether it matters how a state effectuates its substantive criminalization judgments. Subsumed in

${ }^{52}$ See, e.g., McDaniel v. State, 356 So. 2d 1151, 1160-61 (Miss. 1978) ("II]f a person casts off the restraints of reason and consciousness by a voluntary act, no wrong is done to him if he is held accountable for any crimes which he may commit in that condition."); State v. Stasio, 396 A.2d 1129, 1134 (N.J. 1979) ("[Allowing intoxication to have an exculpatory effect] undermines the criminal law's primary function of protecting society from the results of behavior that endangers the public safety."); Note, Intoxication as a Criminal Defense, 55 CoLUM. L. REV. 1210, 1218 (1955) (offering general deterrence as an explanation for limiting intoxication's exculpatory effect).

ss This trend seems to be a motivating factor behind Florida's current reconsideration of its approach to intoxicated wrongdoers. See, e.g., H.B. 417, 15th Leg., 1st Reg. Sess. (Fla. 1997) (finding that sentence reductions based on intoxication should be prohibited because "the victim, whose injuries are no less real and painful because the defendant injured the victim while abusing or while addicted to a substance, and who bears no responsibility for the defendant engaging in such irresponsible behavior, has a reasonable interest in the trial court's applying the full measure of the law when the defendant is convicted of a crime against the victim"). 
the procedural question is a secondary question: Is there any constitutional difference between explicitly redefining a state's substantive criminal law and "implicitly redefining" the law simply by prohibiting defendants from offering evidence otherwise relevant to rebut the State's prima facie case of criminal liability?

Underlying these two principal sets of questions is a normative question: Should intoxication be irrelevant to criminal liability? Put differently, does this treatment of intoxicated wrongdoers achieve the social goals it purports to serve? What are these goals, and by whom are they recognized? ${ }^{34}$ Given present scientific knowledge of intoxication's pharmacological effect, might this treatment of intoxicated wrongdoers transgress a sense of fairness that is short of due process? Is there any better (that is, more effective or fairer) way to achieve the relevant social goals?

In this Part, I argue that (1) the culpability requirement of the criminal law demands that some severely intoxicated wrongdoers be treated differently than sober offenders; and (2) even if all intoxicated wrongdoers constitutionally may be treated the same as sober offenders, procedural due process requires that this treatment be effectuated through the substantive criminal law rather than by limiting a defendant's ability to present intoxication evidence to rebut the State's prima facie case of criminal liability.

\section{B. Montana v. Egelhoff}

As discussed briefly above, in Montana v. Egelhoff, ${ }^{35}$ the Supreme Court upheld against a due process challenge Montana's statutory prohibition on the admission of intoxication evidence for the purpose of negating the mens rea element of the crime charged. ${ }^{36} \mathrm{Be}-$ cause the reasoning of the Supreme Court of Montana is central to the holding of the United States Supreme Court, it is briefly addressed before examining the Supreme Court's ruling.

${ }^{34}$ This question is particularly relevant when one considers that, of the 14 states that treat intoxication as irrelevant to proof of mens rea, only seven (including Montana) do so pursuant to specific statutory authority. See infra note 175 and accompanying text. The courts of four other states have adopted this approach through interpretations of more general statutory provisions, see infra note 187 and accompanying text, and three states have made intoxication irrelevant by judicial decision, see infra note 193 and accompanying text.

${ }^{35} 116$ S. Ct. 2013 (1996).

${ }^{36}$ See MONT. CODE ANN. \$ 45-2-203 (1997) (Montana's exclusionary statute); see also supra note 4. 


\section{Supreme Court of Montana}

The Supreme Court of Montana made clear that it was not considering, nor was it asked to consider, whether Egelhoff had a due process right to an affirmative defense of voluntary intoxication. ${ }^{37}$ Instead, the sole issue decided by the court was whether prohibiting Egelhoff from introducing intoxication evidence for the purpose of negating the mens rea element of deliberate homicide violated due process. The court held that Montana's exclusionary statute precluded Egelhoff from rebutting the State's prima facie case, thereby impermissibly relieving the State of part of its burden to prove all elements of deliberate homicide beyond a reasonable doubt. ${ }^{38}$

At trial, the State offered a significant amount of evidence tending to prove that Egelhoff acted purposely or knowingly in killing the victims. For instance, the State introduced evidence suggesting the following: that Egelhoff had to remove the gun from the glove compartment of Christianson's car before committing the homicides; that Egelhoff attempted to flee after the car ran off the road; that he tried to avoid detection at least twice when witnesses at the scene approached the car; that a stick was found in the car, which would have allowed Egelhoff to operate the car's accelerator from the back seat; that Egelhoff did not appear intoxicated at a supermarket at 9:20 p.m. on the night of the homicides; and that, at the time the car was discovered, Egelhoff had physical strength and coordination, and was able to converse with emergency personnel. ${ }^{39}$

On appeal to the Supreme Court of Montana, Egelhoff argued that, because he was prohibited from introducing evidence of his intoxication to the jury, the State was relieved of its burden of proving the mens rea element of deliberate homicide beyond a reasonable doubt. $^{40}$ The State's response was two-fold: (1) Egelhoff was not prejudiced because he was able to introduce intoxication evidence to show that he was physically incapable of committing the homicides and to explain his memory loss; and (2) due process was not violated because the jury was specifically instructed that the state had the burden of proving beyond a reasonable doubt all elements of deliberate homicide. 4 .

\footnotetext{
${ }^{37}$ See State v. Egelhoff, 900 P.2d 260, 264 (Mont. 1995).

${ }^{3 s}$ See id. at 265 .

${ }^{39}$ See id.

${ }^{10}$ See id. at 264.

${ }^{4}$ See id.
} 
The Supreme Court of Montana began its analysis by holding that the intoxication evidence proffered by Egelhoff was relevant to the issue of whether he acted purposely or knowingly. ${ }^{42}$ The court then relied on Martin v. Ohio, in which the United States Supreme Court held that placing the burden of proving self-defense on the defendant does not violate due process. In dictum, the Martin Court noted:

It would be quite different if the jury had been instructed that selfdefense evidence could not be considered in determining whether there was a reasonable doubt about the State's case, i.e., that self-defense evidence must be put aside for all purposes unless it satisfied the preponderance standard. Such an instruction would relieve the State of its burden and plainly run afoul of Winship's mandate [that the state bears the burden of proving every element of an offense beyond a reasonable doubt]. ${ }^{44}$

The Supreme Court of Montana analogized from this passage in Martin that preventing Egelhoff's jury from considering the intoxication evidence relieved the prosecution of its burden of proving the mens rea element of deliberate homicide beyond a reasonable doubt. $^{45}$ The court further noted that the exclusionary instruction may have misled the jury into believing that the State had, in fact, proved the mens rea element beyond a reasonable doubt. In a sweeping statement of its holding, the court declared: "We conclude that the defendant had a due process right to present and have considered by the jury all relevant evidence to rebut the State's evidence on all elements of the offense charged."

\section{United States Supreme Court}

A badly divided United States Supreme Court reversed the Supreme Court of Montana, stating, in the plurality's words, "[ $t]$ he people of Montana have decided to resurrect the rule of an earlier era, disallowing consideration of voluntary intoxication when a defendant's state of mind is at issue. Nothing in the Due Process Clause prevents them from doing so ...."47 Justice Scalia wrote the plurality opinion, which claimed four votes. Justice O'Connor authored the

${ }^{42}$ See id. at 265 ("It is clear that [evidence of Egelhoff's level of intoxication] was relevant to the issue of whether Egelhoff acted knowingly and purposely ....").

480 U.S. 228 (1987).

14 Id. at 233-34 (citing In re Winship, 397 U.S. 358, 364 (1970)).

${ }^{45}$ Egelhoff, 900 P.2d at 266.

${ }^{46}$ Id.

${ }^{47}$ Montana v. Egelhoff, 116 S. Ct. 2013, 2024 (1996). 
lead dissent, which Justices Stevens, Souter, and Breyer joined. In addition, Justices Souter and Breyer authored separate dissents. The fifth vote for the judgment was cast by Justice Ginsburg, who concurred in the judgment, but not in the plurality opinion.

Two competing positions emerge from the five opinions. First, the plurality argued that states have near-plenary authority over the administration of criminal justice, checked only by the Due Process Clause's proscription of criminal justice procedures that "offend[] some principle of justice so rooted in the traditions and conscience of our people as to be ranked as fundamental.",48 According to the plurality, then, Egelhoff's task was "to establish that a defendant's right to have a jury consider evidence of his voluntary intoxication in determining whether he possesses the requisite mental state is a 'fundamental principle of justice.",49 After reviewing the original common law approach treating intoxication as irrelevant to criminal liability, and the nineteenth century repudiation of this approach, the plurality concluded that:

\begin{abstract}
Although the rule allowing a jury to consider evidence of a defendant's voluntary intoxication where relevant to mens rea has gained considerable acceptance [since the late nineteenth century], it is of too recent vintage, and has not received sufficiently uniform and permanent allegiance to qualify as fundamental, especially since it displaces a lengthy common-law tradition which remains supported by valid [policy] justifications today. ${ }^{50}$
\end{abstract}

The plurality went on to criticize the Montana Supreme Court's reliance on Martin, noting first that the pertinent language from Martin was dictum and, second, that the issue in Martin was a defendant's right to put on evidence of self-defense, a right that might well be "fundamental."

The second position, articulated in Justice O'Connor's dissent, would consider Montana's exclusionary statute constitutional only if the statute "implicitly redefined" the mens rea element of deliberate homicide so as to render intoxication evidence irrelevant to criminal liability. ${ }^{52}$ This approach was adopted by a five-vote majority-the four dissenters and Justice Ginsburg, who concurred in the judgment announced by the plurality. Under this line of argument, "a State

\footnotetext{
IS Id. at 2017 (quoting Patterson v. New York, 432 U.S. 197, $201-02$ (1977)).

49 Id.

so Id. at 2021.

51 Id. at 2023 .

${ }^{52}$ Id. at 2031, (O'Connor, J., dissenting).
} 
may so define the mental element of an offense that evidence of a defendant's voluntary intoxication at the time of commission does not have exculpatory relevance and, to that extent, may be excluded without raising any issue of due process. ${ }^{, 53}$ However, if Montana did not intend or implicitly achieve a redefinition of deliberate homicide through its exclusionary statute, due process requires that the State not prohibit, without valid justification, the defendant's introduction of relevant, exculpatory intoxication evidence. ${ }^{54}$

All four dissenters concluded that (1) the Supreme Court of Montana held that Montana's exclusionary statute does not redefine the mens rea element of deliberate homicide, and that this determination of state law is unreviewable by the United States Supreme Court: ${ }^{55}$ and (2) in the absence of a redefinition of deliberate homicide, Montana had not put forth a valid justification for excluding the intoxication evidence. ${ }^{56}$

Justice Ginsburg, concurring in the judgment, adopted the dissent's approach but concluded that Montana's exclusionary statute in fact implicitly redefined the mens rea element of deliberate homicide, changing it from "purposely or knowingly" to "under circumstances that would otherwise establish knowledge or purpose 'but for'

ss Id. at 2032 (Souter, J., dissenting).

${ }^{54}$ See id. at 2027 (O'Connor, J., dissenting) ("A state legislature certainly has the authority to identify the elements of the offenses it wishes to punish, but once its laws are written, a defendant has the right to insist that the State prove beyond a reasonable doubt every element of an offense charged.").

${ }^{55}$ Federal courts are bound by state courts' interpretations of state law. See, e.g., Minnesota v. Clover Leaf Creamery Co., 449 U.S. 456, 481 \& n.5 (1981) (Stevens, J., dissenting) (citing cases for this "well-established" proposition). But see Larry Alexander, The Supreme Court, Dr. Jekyll, and the Due Process of Proof, 1996 SUP. CT. REV. 191, 208-09 (1997) (acknowledging the binding effect on federal courts of state court determinations of state law, but opining in reference to Egelhoff that "when the only effect the Montana Supreme Court's 'interpretation' of state law will have is how the federal Due Process Clause applies to state law, that court should have no power to bind the federal courts to its interpretation").

Although the Supreme Court of Montana relied on the Federal Due Process Clause in Egelhoff, its interpretation of Montana's exclusionary statute clearly would affect the applicability of Montana's due process clause, MONT. CONST. art. II, $\S 17$. This limits the import of Professor Alexander's position. In fact, the Supreme Court of Montana has signaled its willingness to reaffirm its decision in Egelhoff under the Montana Constitution. See Byers v. Mahoney, 929 P.2d 202, 205 (Mont. 1996) ("Although we have declined to readdress Egelhoff at this time, this does not preclude our review of Egelhoff on adequate and independent state grounds under the appropriate circumstances.").

${ }^{56}$ See Egelhoff, 116 S. Ct. at 2028-29, 2031 (O'Connor, J., dissenting). 
[the defendant's] voluntary intoxication." ${ }^{57}$ Justice Ginsburg concluded that, "[c]omprehended as a measure redefining mens rea, [Montana's exclusionary statute] encounters no constitutional shoal. ${ }^{n 8}$

The four-vote plurality viewed the implicit redefinition inquiry as superfluous. According to the plurality, the legislature's judgment that intoxication is irrelevant to criminal liability "may be implemented... with equal legitimacy by amending the substantive requirements for each crime, or by simply excluding intoxication evidence from the trial. ${ }^{, 59}$

\section{The Due Process Analysis}

As one might expect, it is difficult to say what "law" comes out of Egelhoff. At the end of the day, there are seven votes for the proposition that a state may treat intoxicated wrongdoers criminally liable to the same extent as sober offenders by implicitly redefining the mens rea element of its criminal offenses. ${ }^{60}$ A clear majority of the Court therefore answered the criminalization question in the affirmative: A state may, consistent with substantive due process, treat severely intoxicated wrongdoers and sober offenders alike. In addition, five Justices $^{61}$ construed Montana's exclusionary statute as effecting an implicit redefinition of the state's substantive criminal law, even over the unanimous protest of the state's highest court.

The four dissenters refused to read Montana's exclusionary statute as an implicit redefinition of the mens rea element of deliberate homicide and would have held that a criminalization judgment effectuated through an evidentiary proscription can, and in Egelhoff did, violate procedural due process. Although Justice Ginsburg agreed with the dissenters on this point, her liberal reading of Montana's exclusionary statute as an implicit redefinition of the state's substantive criminal law severely limits the practical import of her agreement with the dissent.

${ }^{37}$ Id. at 2024 (Ginsburg, J., concurring in the judgment) (quoting Brief for American Alliance for Rights and Responsibilities et al. as Amicus Curiae at 6 (No. 95-566)).

${ }^{5 s}$ Id. (Ginsburg, J., concurring in the judgment).

${ }^{59}$ Id. at 2020-21 n.4. (Ginsburg, J., concurring in the judgment).

${ }^{60}$ Justices Breyer and Stevens reserved judgment on this proposition. See infra note 62 and accompanying text.

${ }^{61}$ The five Justices are the plurality (Chief Justice Rehnquist and Justices Scalia, Kennedy, and Thomas) and the concurrence (Justice Ginsburg). 
Egelhoff holds, then, that a statute that prohibits the admission of intoxication evidence satisfies due process if (liberally read) it redefines the mens rea element of a crime so as to render intoxication irrelevant to criminal liability.

\section{The Criminalization Question}

Justices Breyer and Stevens reserved judgment on whether a state may define the mens rea element of a crime so as to make intoxication evidence irrelevant to guilt. ${ }^{62}$ The other seven Justices declared, with little argument, that such a criminal statute is constitutional. ${ }^{63}$ In fact, Justice Ginsburg viewed this as the sole and determinative issue in the case:

Beneath the labels (rule excluding evidence or redefinition of the offense) lies the essential question: Can a State, without offense to the Federal Constitution, make the judgment that two people are equally culpable where one commits an act stone sober, and the other engages in the same conduct after his voluntary intoxication has reduced his capacity for self control? ${ }^{64}$

The plurality, too, viewed the criminalization question as determinative, although its due process analysis approached the constitutionality of Montana's exclusionary statute as an evidentiary proscription rather than as an implicit redefinition of Montana's substantive criminal law. ${ }^{65}$

62 See Egelhoff, 116 S. Ct. at 2035 (Breyer, J., dissenting).

${ }^{63}$ See id. at 2024 ("The people of Montana have decided to resurrect the rule of an earlier era, disallowing consideration of voluntary intoxication when a defendant's state of mind is at issue. Nothing in the Due Process Clause prevents them from doing so ...."); id. (Ginsburg, J., concurring in the judgment) ("Comprehended as a measure redefining mens rea, $\S 45-2-203$ encounters no constitutional shoal."); id. at 2031 (O'Connor, J., dissenting) ("If the Montana legislature chose to redefine [deliberate homicide] so as to alter the requisite mental-state element, the due process problem presented in this case would not be at issue."); id. at 2032 (Souter, J., dissenting) ("I have no doubt that a State may so define the mental element of an offense that evidence of a defendant's voluntary intoxication at the time of commission does not have exculpatory relevance and, to that extent, may be excluded without raising any issue of due process.").

${ }^{64} I d$. at 2024 (Ginsburg, J., concurring in the judgment).

${ }^{65}$ The plurality viewed a redefinition of a substantive crime and an evidentiary proscription as equally legitimate means to render intoxication irrelevant to criminal liability. See supra note 59 and accompanying text. The plurality subsumes the criminalization argument under its due process analysis of $\S 45-2-203$ as an evidentiary proscription, "simply because that is how the Supreme Court of Montana chose to analyze it." Egelhoff, 116 S. Ct. at 2020 n.4. 


\section{a. The Culpability Requirement in Criminal Law}

The general principle that criminal liability should be based on moral culpability, and thus predicated on intentional conduct, is deeply rooted in Anglo-American criminal law. ${ }^{66}$ This principle is embodied in the presumption against strict liability in the criminal context, perhaps most articulately stated nearly fifty years ago by Justice Jackson:

The contention that an injury can amount to a crime only when inflicted by intention is no provincial or transient notion. It is as universal and persistent in mature systems of law as belief in freedom of the human will and a consequent ability and duty of the normal individual to choose between good and evil. A relation between some mental element and punishment for a harmful act is almost as instinctive as the child's familiar exculpatory "But I didn't mean to," and has afforded the rational basis for a tardy and unfinished substitution of deterrence and reformation in place of retaliation and vengeance as the motivation for public prosecution. ${ }^{67}$

Despite this strong intellectual commitment to the notion that criminal liability must be premised on a guilty mind, the Court has

${ }^{6}$ See 2 James FitzJames STEPHEN, A History OF the CRIMINAL LAW OF ENGLAND 97, 123 (Burt Franklin 1964) (1883) (ranking intention as a condition of criminal liability, but recognizing manslaughter as based on negligent omission); see also Dennis v. United States, 341 U.S. 494, 500 (1951) ("The existence of a mens rea is the rule of, rather than the exception to, the principles of Anglo-American criminal jurisprudence."); Jerome Hall, Negligent Behavior Should Be Excluded from Penal Liability, 63 COLUM. L. REv. 632, 634-43 (1963) (discussing historical, ethical, and scientific reasons for requiring intentional conduct for criminal liability); Henry M. Hart, Jr., The Aims of the Criminal Law, 23 LAW \& CONTEMP. PROBS. 401, 423 (1958) ("In the tradition of Anglo-American law, guilt of crime is personal. The main body of the criminal law, from the Constitution on down, makes sense on no other assumption."); John Calvin Jeffries, Jr. \& Paul B. Stephan III, Defenses, Presumptions, and Burden of Proof in the Criminal Law, 88 YALE L.J. 1325, 1376 (1979) ("As a question of principle ... there can be little doubt of the morally objectionable character of liability without fault or of its inconsistency with the traditional Anglo-American concept of fairness to the individual."). But see George P. Fletcher, The Theory of Criminal Negligence: A Comparative Analysis, 119 U. PA. L. REV. 401, 408-26 (1971) (arguing that negligence may form the basis of criminal liability).

${ }^{67}$ Morissette v. United States, 342 U.S. 246, 250-51 (1952) (footnotes omitted); see also MODEL PENAL CODE $\S 2.05 \mathrm{cmt} .1$ (1985) ("This section makes a frontal attack on ... strict liability in the penal law, whenever the offense carries the possibility of criminal conviction, for which a sentence of probation or imprisonment may be imposed.... Crime does and should mean condemnation and no court should have to pass that judgment unless it can declare that the defendant's act was culpable. This is too fundamental to be compromised." (footnote omitted)). 
never constitutionalized this principle. ${ }^{68}$ In fact, the Court has upheld the imposition of strict liability in prosecutions under public welfare statutes $^{69}$ and as to the so-called jurisdictional elements of offenses. ${ }^{70}$ Add to these examples the traditional exceptions to the mens rea requirement the common law made for statutory rape, ${ }^{71}$ felony murder, ${ }^{72}$ and involuntary manslaughter, ${ }^{73}$ and it becomes clear that the mens rea "requirement," although persistent in theory, has not been held by the Court to be a requirement of substantive due process.

\section{b. "Negligent Deliberate" Homicide}

Montana's exclusionary statute does not, of course, impose a strict liability standard for deliberate homicide. Justice Ginsburg, prompted by amicus, suggested that it imposes a standard of "under circumstances that would otherwise establish knowledge or purpose 'but for' [the defendant's] voluntary intoxication." ${ }^{74}$ This formulation of the mens rea element, while technically accurate, is too innocuous; "but for a defendant's intoxication" goes a long way in

${ }^{6}$ See, e.g., Powell v. Texas, 392 U.S. 514, 535 (1968) (stating that the Court "has never articulated a general constitutional doctrine of mens rea"); Lambert v. California, 355 U.S. 225, 228 (1957) ("We do not go with Blackstone in saying that 'a vicious will' is necessary to constitute a crime ... for conduct alone without regard to the intent of the doer is often sufficient."); Jeffries \& Stephan, supra note 66, at 1374 ("Constitutional acceptance of a requirement of culpability ... is at best uncertain.").

${ }^{69} \mathrm{See}$ United States v. Balint, 258 U.S. 250, 252 (1922) ("Many instances of [strict liability] are to be found in regulatory measures in the exercise of what is called the police power where the emphasis of the statute is evidently upon achievement of some social betterment rather than the punishment of the crimes as in cases of mala in se.").

${ }^{70}$ See United States v. Feola, 420 U.S. 671, 685 (1975) ("The concept of criminal intent does not extend so far as to require that the [offender] understand not only the nature of his act but also its consequence for the choice of a judicial forum.").

${ }^{71}$ See Regina v. Prince, 2 L.R.-Cr. Cas. Res. 154, 163 (Eng. Cr. Cas. Res. 1875) (finding that some prohibited acts may be classified as crimes even "in the absence of the knowledge or intent supposed necessary to constitute a mens rea"); see also People v. Olsen, 685 P.2d 52, 57 (Cal. 1984) (en banc) (asserting that "a reasonable mistake as to the [statutory rape] victim's age would not be a defense").

${ }^{72}$ See Regina v. Serné, 16 Cox Crim. Cas. 311, 313 (Eng. Cent. Crim. Ct. 1887) ("$[A]$ ny act known to be dangerous to life, and likely in itself to cause death done for the purpose of committing a felony which caused death, should be murder."); see also People v. Stamp, 82 Cal. Rptr. 598, 603 (Ct. App. 1969) ("[A] felon is held strictly liable for all killings committed by him or his accomplices in the course of the felony.").

${ }^{73}$ See, e.g., State v. Powell, 426 S.E.2d 91, 95 (N.C. Ct. App. 1993) (noting that "violation of [a] statute designed for the protection of others is negligence per se" (citation omitted)).

${ }^{71}$ Egelhoff, 116 S. Ct. at 2024 (Ginsburg, J., concurring in the judgment) (quoting Brief for American Alliance for Rights and Responsibilities et al. as Amicus Curiae at 6 (No. 95-566)). 
transforming the actual intent required to convict a defendant of deliberate homicide. Assuming that severe intoxication can, as a pharmacological matter, prevent the subjective formulation of "knowledge" or "purpose," the standard recognized by Justice Ginsburg is negligence. If the defendant had acted reasonably (i.e., had he not been intoxicated), he would not have caused the death for which he is prosecuted. According to Justice Ginsburg, the pivotal vote in Egelhoff, Montana has permissibly established a negligence standard for deliberate homicide. This stretches beyond the breaking point the tenuous practice of imposing criminal liability absent a showing of subjective intent.

Although establishing a negligence standard for homicide is nothing new, ${ }^{76}$ designating such a crime deliberate homicide-which in Montana, as in many states, is a capital crime ${ }^{77}$-is remarkable indeed. $^{78}$ The very notion of a crime of "negligent deliberate homicide"

${ }^{75}$ The scientific evidence on this point is notoriously sketchy. Even if medical knowledge concerning the pharmacological effects of intoxicants were more complete, whether intoxication can prevent the formation of intent would still be dependent on conclusively defining what one means by "intent." Many commentators argue that the vast majority of intoxicated wrongdoers "intend" the harms they cause. See, e.g., Jerome Hall, Intoxication and Criminal Responsibility, 57 HARV. L. REV. 1045, 1065 (1944) ("II]ntent is present in harms by inebriates; typically what is lacking is control and ethical sensitivity."); Stephen J. Morse, Undiminished Confusion in Diminished Capacity, 75 J. CRIM. L. \& CRIMINOLOGY 1, 16-18 (1984) (concluding that intoxication rarely, if ever, renders a person incapable of forming intent).

This position, even if correct in some sense, does not end the inquiry. As Hall explains, "the salient fact [is] that there was never an intent to kill or seriously injure by a sober person." Hall, supra, at 1065. As other respected authorities have put it, "what is crucial to the assessment of the moral culpability of the intoxicated offender, then, is not absence of intent... but absence of an intent formed by a rational mind" HERBERT FINGARETTE \& ANN HASSE, MENTAL DISABILITIES AND CRIMINAI RESPONSIBILITY 99 (1979).

${ }^{76}$ See, e.g., State v. Williams, 484 P.2d 1167, 1171 (Wash. Ct. App. 1971) (applying standard of ordinary (tort) negligence to affirm conviction of manslaughter); MODEL PENAL CODE $\$ 210.4$ (1985) (defining negligent homicide to require a gross deviation from the standard of care that a reasonable person would observe in the actor's situation).

" See MONT. CODE ANN. § 45-5-102(2) (1997) (designating deliberate homicide a capital crime).

${ }_{78}$ Remarkable, but not unprecedented. The felony murder rule theoretically can have the same effect. See, e.g., People v. Washington, 402 P.2d 130, 133 (Cal. 1965) ("The purpose of the felony-murder rule is to deter felons from killing negligently or accidentally by holding them strictly responsible for killings they commit."). More over, not even the actus reus requirement need actually be fulfilled for felony murder liability to apply. See, e.g., People v. Hernandez, 624 N.E.2d 661, 662 (N.Y. 1993) (upholding a robber's felony murder conviction where a police officer was fatally shot by another police officer during the course of a gun battle with the robber). 
seems nonsensical. It is unlikely that the Montana legislature intended to create such a crime. If the legislature had intended this result, why would it retain the express subjective mens rea element of deliberate homicide? ${ }^{79}$ Whether resulting from legislative sleight of hand or the legislature's failure to appreciate the change wrought in the substantive law by its exclusionary statute, the end result is a negligence standard for deliberate homicide, thinly disguised by a de jure requirement of purpose or knowledge.

Despite the Court's reluctance to constitutionalize the culpability requirement by making intentional conduct the touchstone of criminal liability, treating Montana's exclusionary statute as implicitly establishing a negligence standard for deliberate homicide is both unprecedented and unprinicipled. ${ }^{80}$ Such a standard raises other fairness concerns, apart from due process, which are discussed below. ${ }^{81}$

As a practical matter, however, the dangerous nature of felonization assures that the subjective mens rea of recklessness will almost always be present in felony murder convictions. Doctrinal limits on the felony murder rule also make it less likely that merely negligent felons will be subject to prosecution for deliberate homicide. See, e.g., People v. Smith, 678 P.2d 886, 887 (Cal. 1984) (finding that "the acts constituting [the offense] ... were an integral part of the homicide, [thus] the offense merged into the homicide [and] it was therefore error to give a felony murder instruction"); People v. Phillips, 414 P.2d 353, 360 (Cal. 1966) (noting that only felonies that are inherently dangerous to human life justify the application of the felony murder rule); State v. Canola, 374 A.2d 20, 30 (N.J. 1977) (prohibiting extension of the felony murder rule "to lethal acts of third persons not in furtherance of the felon[ious] scheme"). But see Clayton v. State, 272 So. 2d 860, 861 (Fla. Dist. C.t. App. 1973) (holding ingestion of LSD to be an inherently dangerous felony sufficient to support a felony murder conviction).

${ }^{79}$ Justice Breyer made a similar argument in his Egelhoff dissent. See Egelhoff, $116 \mathrm{~S}$. Ct. at 2035 (Breyer, J., dissenting) ("If the legislature wanted to equate voluntary intoxication, knowledge, and purpose, why would it not write a statute that plainly says so...?"?).

${ }^{80}$ Some scholars have argued that the Eighth Amendment's prohibition of cruel and unusual punishments protects against conviction of murder absent proof of malice. See Nelson E. Roth \& Scott E. Sundby, The Felony-Murder Rule: A Doctrine at Constitutional Crossroads, 70 CORNELL L. REV. 446, 478-85 (1985) (arguing that eliminating the malice element violates the Eighth Amendment requirement that punishments be proportional to culpability). This argument is severely undermined by the Court's narrow reading of the Eighth Amendment's proportionality requirement. See Harmelin v. Michigan, 501 U.S. 957, 959 (1991) ("[T] he Eighth Amendment does not require strict proportionality between crime and sentence, but rather forbids only extreme sentences that are grossly disproportionate to the crime.").

${ }^{81}$ See infra Part III.C.2.e. 


\section{The Procedural Question}

As noted above, the plurality in Egelhoff would hold that there is no due process bar to Montana's exclusionary statute properly understood as an evidentiary proscription, rather than a redefinition of the state's substantive criminal law. Although this argument commanded only four votes, it has already proven persuasive to lower courts and state legislatures that have read Egelhoff as validating evidentiary proscriptions that pass the plurality's due process analysis. ${ }^{82}$ Due to the broad reading Egelhoff has been given, and because the main thrust of the Egelhoff dissents is aimed precisely against this proposition, it is important to give it serious consideration.

${ }^{82}$ See, e.g., Chavez v. Shanks, No. 95-2264, 1997 WL 191498, at *1 (10th Cir. Apr. 18, 1997) ("The Supreme Court last year [in Egelhoff] rejected the argument that [the right to present intoxication evidence to negate mens rea] is a fundamental right enshrined in the Constitution under the Fourteenth Amendment."); Melendez v. Parke, No. 95-2332, 1996 WL 459924, at *2 (7th Cir. July 26, 1996) ("The Supreme Court held [in Egelhoff] that [the Montana statute] does not violate the Due Process Clause, because it offends neither a fundamental principle of fairness nor the requirement that the state prove mens rea beyond a reasonable doubt." ); Lamarsh v. Roe, No. 964233,1997 WL 414200 , at $* 2$ (N.D. Cal. July 14, 1997) (citing Egelhoff for the proposition that "[ $t]$ he exclusion of evidence does not violate the Due Process Clause unless it offends some principle of justice so rooted in the traditions and conscience of our people as to be ranked as fundamental"); Gazali v. Cambra, No. 96-3149, 1997 WL 294411, at *8 (N.D. Cal. May 20, 1997) (same); Young v. Kernan, No. 95-4103, 1996 WL 681974, at *7 (N.D. Cal. Nov. 19, 1996) (citing Egelhoff for the proposition that "[t]o demonstrate a violation of the Due Process Clause, the defendant must establish that his right to have the jury consider the excluded evidence in the case was a 'fundamental principle of justice'"); Geiger v. Morton, No. 95-5290, 1996 WL 361474, at *4 (D.N.J. June 24, 1996) ("In Egelhoff, the Court explained that a defendant's right to present evidence of voluntary intoxication to negate a requisite mental state is not a 'fundamental' principle of justice."); State v. Mott, 931 P.2d 1046, 1052 (Ariz. 1997) (en banc) ("The [Egelhoff] Court concluded that barring ... evidence of voluntary intoxication does not violate the constitution."); State v. Fanning, 939 S.W.2d 941, 944 45 (Mo. Ct. App. 1997) ("The [Egelhoff] Court held that it is the respondent who must show that the principle of procedure violated by the rule (and allegedly required by due process) is so rooted in the traditions and conscience of our people as to be ranked as fundamental." (quotations omitted)); State v. Pointer, 932 S.W.2d 871, 874 (Mo. Ct. App. 1996) ("The United States Supreme Court determined [in Egelhoff] that a defendant's right to have a jury consider evidence of his voluntary intoxication does not constitute ... a fundamental principle in American jurisprudence."); S.B. 168 \& 88, 15th Leg., 1st Reg. Sess. (Fla. 1997) ("In [Egelhoff], the United States Supreme Court held that the Due Process Clause of the Fourteenth Amendment was not violated by a Montana law barring a jury in a criminal proceeding from considering evidence of a defendant's voluntary intoxication in determining the existence of a mental state that is an element of a crime."). But see United States v. Scheffer, 44 M.J. 442, 447-48 (C.A.A.F. 1996) (noting that the Egelhoff plurality's reasoning did not command a majority of the Court); State v. Brown, 931 P.2d 69, 76 (N.M. 1996) (same). 


\section{a. "The Traditions and Conscience of Our People"}

The plurality began its analysis of Montana's exclusionary statute by stating the test that has been used in postincorporation residual due process jurisprudence: A state's procedural rule violates the Due Process Clause only if "it offends some principle of justice so rooted in the traditions and conscience of our people as to be ranked as fundamental." ${ }^{38}$ Applying this test, the plurality asserted that Egelhoff must have established that "a defendant's right to have a jury consider evidence of his voluntary intoxication in determining whether he possesse[d] the requisite mental state is a 'fundamental principle of justice." ${ }^{84}$ Noting that historical practice is the "primary guide" when determining whether a principle is fundamental, the plurality reviewed the common law history of using intoxication evidence to negate mens rea. ${ }^{85}$ The plurality then concluded that the common law was in flux at the time the Fourteenth Amendment was adopted, with the specific intent doctrine just taking root, and that such equivocal support for intoxication's exculpatory effect was insufficient to render it a fundamental principle of justice. ${ }^{86}$ Therefore, Montana's exclusionary statute did not violate due process.

There is little doubt that the common law treatment of intoxication evidence was unsettled in the latter half of the nineteenth century. Although the specific intent doctrine had a significant toehold by that time and would eventually gain wide acceptance, ${ }^{87}$ as late as 1858 one state court claimed:

To look for deliberation and forethought in a man maddened by intoxication is vain, for drunkenness has deprived him of the deliberating faculties to a greater or less extent; and if this deprivation is to relieve him of all responsibility or to diminish it, the great majority of crimes committed will go unpunished. This however is not the doctrine of the common law; and to its maxims, based as they obviously are upon true wisdom and sound policy, we must adhere.

${ }^{8 s}$ Egelhoff, 116 S. Ct. at 2017 (quoting Patterson v. New York, 432 U.S. 197, 202 (1977)).

\footnotetext{
${ }^{84}$ Id. at 2017.

${ }^{85}$ See id. at 2017-20.

${ }^{86}$ See id. at 2021.

${ }^{87}$ See supra notes 20-21 and accompanying text.

${ }^{8 s}$ State v. Cross, 27 Mo. 332, 338 (1858).
} 
The Egelhoff plurality's conclusion on this matter, then, is uncontroversial. $^{89}$ The question remains, though, whether the plurality conducted the proper inquiry in the first place. Despite the plurality's assertion that Egelhoff's task was to establish as fundamental the "right to have a jury consider evidence of his voluntary intoxication in determining whether he possesse[d] the requisite mental state," ${ }^{\prime 90}$ the due process test itself does not compel such a narrow formulation of the right at issue.

\section{b. Which "Principle of Justice"?: The Inadequacies of the Specificity Approach to Due Process Analysis}

Formulating the putative right to be measured under the due process test is perhaps the most important and controversial step in due process analysis-whether an asserted right is protected by the Due Process Clause is in large part derivative of the linguistic formulation of that right. The level of generality at which an asserted right is formulated may either bring it within the protection of a recognized due process right, or exclude it from protection under the Due Process Clause. ${ }^{91}$ If the fundamental right at issue in Egelhoff had been characterized more generally as the defendant's "right to a fair opportunity to put forward his defense, in adversarial testing where the State must prove the elements of the offense beyond a reasonable doubt, "92 the outcome of the due process inquiry may have been different. At the very least, the due process inquiry would not have ceased upon finding that intoxication evidence was not universally admissible to negate mens rea at common law. Instead, an analysis of the recognized due process right to present a defense would have been dispositive.

The levels of generality problem is one that has divided the Court and the academy along readily discernible ideological lines. The approach taken depends, in part, on one's view of the role of the judge

${ }^{89}$ All of the dissenters agreed that the common law was unsettled on this point. See Egelhoff, 116 S. Ct. at 2031 (O'Connor, J., dissenting) ("At the time the Fourteenth Amendment was ratified, the common-law rule on consideration of intoxication evidence was in flux.").

${ }^{90} \mathrm{Id}$. at 2017.

${ }^{91}$ This is referred to as the "levels of generality problem," and has received significant attention from the academic bar. See, e.g., Laurence H. Tribe \& Michael C. Dorf, Levels of Generality in the Definition of Rights, 57 U. CHI. L. REv. 1057 (1990) (discussing this problem extensively).

${ }_{92}$ Egelhoff, 116 S. Ct. at 2031 (O'Connor, J., dissenting). 
in constitutional interpretation and of the nature of the Constitution itself. Is the Constitution a "living document," which judges are charged with interpreting in the face of ever-evolving ideals of fairness and justice? Or is the Constitution a document that is necessarily limited in scope, which judges must interpret by considering only its text? $^{93}$ Happily, these larger questions are beyond the scope of this Comment. However, the levels of generality problem is of central importance to evaluating the plurality's analysis, and, therefore, deserves attention here.

Justice Scalia, who authored the plurality opinion in Egelhoff, has made his solution to the levels of generality problem clear elsewhere. In Michael H. v. Gerald $D .{ }^{94}$ he argued that, in characterizing the right at issue in due process analyses, the Court must "refer to the most specific level at which a relevant tradition protecting, or denying protection to, the asserted right can be identified." 95 A more general inquiry would, according to Justice Scalia, "permit judges to dictate rather than discern ... society's views." ${ }^{, 96}$ In Michael $H$., the right so characterized was the right of the natural father of an illegitimate child to claim parental rights against the mother's husband. ${ }^{97}$ In Egelhoff, the right so characterized was the right to negate mens rea with intoxication evidence, because tradition (that is, the common law)

${ }^{93}$ Of course, this characterization of the opposing positions is overly simplistic. Few would argue that judges have unfettered reign over constitutional interpretation. Likewise, as Professors Tribe and Dorf note, "adherents of a philosophy of judicial restraint generally admit that in spelling out the meaning of vague constitutional phrases justices must indeed look beyond the Constitution," usually to the intent of the drafters, whether determined by direct evidence or by inference from historical tradition. Tribe \& Dorf, supra note 91, at 1062-63.

The characterization of the recognized due process right is also subject to the levels of generality problem. "The more abstractly one states the already-protected right, the more likely it becomes that the claimed right will fall within its protection." Id. at 1058. This aspect of the levels of generality problem is most conspicuously at issue in the unenumerated rights debate, where the central issue is how broadly to read constitutional provisions. Compare Ronald Dworkin, Unenumerated Rights: Whether and How Roe Should Be Overruled, 59 U. CHI. L. REV. 381, 381 (1992) (arguing that "the distinction between enumerated and unenumerated rights [should be] safely shut up with other legal concepts dishonorably discharged for bad philosophy"), with Richard A. Posner, Legal Reasoning from the Top Down and from the Bottom Up: The Question of Unenumerated Constitutional Rights, 59 U. CHI. L. REV. 433, 437 (1992) (arguing that failing to distinguish unenumerated rights from enumerated rights is a hallmark of constitutional theorizing that "goes beyond and eventually submerges textual distinctions").

${ }^{94} 491$ U.S. 110 (1989).

${ }^{95}$ Id. at $127-28$ n.6.

${ }^{6} \mathrm{Id}$.

${ }^{97}$ See id. 
speaks to this specific right. Similarly, Justice Scalia's specificity approach dictates that the right at issue in Bowers v. Hardwick ${ }^{98}$ was the "right to engage in homosexual sodomy," because the common law, statutory law, and "Judeao-Christian moral and ethical standards" prohibited such conduct.

By its own terms, the polestar of the specificity approach is "tradition"-in particular, the traditional notions of justice that predominated in 1868, when the Fourteenth Amendment was ratified. Reading the Due Process Clause as codifying nineteenth-century traditions of procedural and substantive justice has been sharply criticized by other members of the Court. For example, in response to Justice Scalia's argument in Michael $H$., Justice Brennan, joined by Justices Marshall and Blackmun, maintained:

Apparently oblivious to the fact that [the concept of "tradition"] can be as malleable and as elusive as "liberty" itself, the plurality pretends that tradition places a discernible border around the Constitution. The pretense is seductive; it would be comforting to believe that a search for "tradition" involves nothing more idiosyncratic or complicated than poring through dusty volumes on American history.

... Just as common-law notions no longer define the "property" that the Constitution protects, neither do they circumscribe the "liberty" that it guarantees.

For Justice Brennan, this point goes to the very essence of the nature of the Constitution and the interpretive role of the judge:

The document that the plurality construes today is unfamiliar to me. It is not the living charter that I have taken to be our Constitution; it is instead a stagnant, archaic, hidebound document steeped in the prejudices and superstitions of a time long past. This Constitution does not recognize that times change, does not see that sometimes a practice or rule outlives its foundations. I cannot accept an interpretive method that does such violence to the charter that I am bound by oath to uphold. ${ }^{102}$

s3 478 U.S. 186 (1986).

${ }^{59}$ Id. at 191.

${ }^{100}$ Id. at 196 (Burger, C.J., concurring) (citations omitted).

${ }^{101} 491$ U.S. at 137-38 (Brennan, J., dissenting) (citations omitted).

${ }^{102}$ Id. at 141 (Brennan, J., dissenting). Professor Dworkin has voiced similarly visceral objections to the role of tradition as dispositive of constitutional questions. See Dworkin, supra note 93, at 384 (criticizing originalism as portraying the Constitution "not as defining the skeleton of an overall conception of justice, but as only an antique list of the particular demands that a relatively few people long ago happened to think important. [Such an approach] hopes to turn the Bill of Rights from a constitutional 
Because I do not wish to belabor these and other theory-based criticisms of the specificity approach, ${ }^{103}$ I will simply offer two further objections that are usually overlooked in the race toward constitutional theorizing: Justice Scalia's specificity approach has been expressly rejected by a majority of the current Court, and its operation leads to clearly wrong results.

The specificity approach not only was eschewed by a majority of the Court at its inception, but also fails to account for the Court's many due process cases that decidedly have not been based on a historical analysis of the most specifically identifiable formulation of the asserted right. Although, as noted above, Justice Scalia's specificity approach was employed sub silentio by the Court in Bowers (a preMichael $H$. case), the dissent in that case pointedly questioned its use:

This case is no more about "a fundamental right to engage in homosexual sodomy," as the Court purports to declare, than Stanley v. Georgia was about a fundamental right to watch obscene movies, or Katz $v$. United States was about a fundamental right to place interstate bets from a telephone booth. ${ }^{104}$

Opposition to Justice Scalia's specificity approach crystallized into a majority position in Planned Parenthood v. Casey: "It is ... tempting ... to suppose that the Due Process Clause protects only those practices, defined at the most specific level, that were protected against government interference by other rules of law when the Fourteenth Amendment was ratified. But such a view would be inconsistent with our law." 105

There is a second basic problem with the specificity approach: It leads to results that are clearly wrong. If, as the specificity approach mandates, contrary common law treatment regarding a specific challenged practice always trumped the assertion of a right putatively guaranteed by the Due Process Clause, some of the Court's most clearly correct decisions would fall. For instance, despite the fact that most states barred interracial marriage in 1868 , few would dispute the

charter into a document with the texture and tone of an insurance policy or a standard form commercial lease.").

${ }^{109}$ Other theory-based objections are voiced in Tribe \& Dorf, supra note 91, at 1072-85 (comparing analogies of law to literature versus mathematics).

${ }^{104}$ Bowers v. Hardwick, 478 U.S. 186, 199 (Blackmun, J., dissenting) (citations omitted) (citing Stanley v. Georgia, 394 U.S. 557 (1969), and Katz v. United States, 389 U.S. 347 (1967)).

${ }^{105} 505$ U.S. 833, 847 (1992) (citation omitted). 
correctness of the Court's decision in Loving $v$. Virginia, ${ }^{106}$ which struck down such antimiscegenation laws as violative of due process. Brown v. Board of Education, too, would be jeopardized; segregated public education was well-rooted in the "history and traditions of our people" when it was found to violate due process in $1954{ }^{107}$

Likewise, the specificity approach arguably lets stand some of the Court's most clearly wrong decisions. A particularly tragic example is Buck $v$. Bell, in which the Court rejected a due process challenge to a Virginia statute mandating the compulsory sterilization of institutionalized persons with the infamous remark that " $[t]$ hree generations of imbeciles are enough." ${ }^{108}$ As a result of that decision, Carrie Buck was forcibly sterilized, only to be found years later to be a woman of normal intelligence who was institutionalized by her foster parents to cover up an incestuous rape that resulted in her pregnancy. ${ }^{109}$ Would Justice Scalia reaffirm Buck? Under the specificity approach, a due process challenge to compulsory sterilization would require a claimant to show a deeply rooted tradition of being free from such procedures. In fact, involuntary sterilization enjoys a nearly one-hundredyear heritage in our society. ${ }^{110}$

Nor can all such cases easily be dismissed as equal protection, rather than due process, cases. Buck, for example, raised no equal protection problem in Justice Holmes's mind. ${ }^{11}$ Even under modern equal protection jurisprudence, there seems to be no equal protection problem: Heightened scrutiny ${ }^{112}$ seems inappropriate since

${ }^{106} 388$ U.S. 1 (1967).

${ }^{107}$ See Brown v. Board of Educ., 347 U.S. 483, 493 (1954); see also Rutan v. Republican Party, 497 U.S. 62, 82 (1990) (Stevens, J., concurring) (" [I]f the age of a pernicious practice were a sufficient reason for its continued acceptance, the constitutional attack on racial discrimination would, of course, have been doomed to failure." (citation omitted) (footnote omitted) (quoting Illinois State Employees Union v. Lewis, 473 F.2d 561, 568 n.14 (7th Cir. 1972) (citation omitted))).

${ }^{103} 274$ U.S. 200, 207 (1927) (Holmes, J.).

${ }^{109}$ See Stephen Jay Gould, Carrie Buck's Daughter, 2 CONST. COMMENTARY 331, 336 (1985).

${ }^{110}$ See Elizabeth J. Reed, Note, Criminal Law and the Capacity of Mentally Retarded Persons to Consent to Sexual Activity, 83 VA. L. REV. 799, 803-05 (1997) (discussing the history of involuntary sterilization in the United States); see also DEL. CODE ANN. tit. 16, $\S 5704$ (1995) (permitting involuntary sterilization).

${ }^{111}$ See Buck, 274 U.S. at 208 (referring to equal protection claims as "the usual last resort of constitutional arguments").

112 See generally Loving v. Virginia, 388 U.S. 1, 11 (1967) ("At the very least, the Equal Protection Clause demands that racial classifications... be subjected to the 'most rigid scrutiny,' and, if they are ever to be upheld, they must be shown to be necessary to the accomplishment of some permissible state objective, independent of the 
"imbeciles" are not a suspect or quasi-suspect class, Carrie Buck was white, Virginia sterilized both sexes, and a rational basis ${ }^{113}$ for the law was, and still is, thought to be apparent. ${ }^{114}$ A theory of due process that permits the state forcibly to sterilize its citizens upon an asserted interest in preventing "socially inadequate offspring" is troublesome indeed. ${ }^{115}$

When pushed, Justice Scalia rebuts the argument that the specificity approach to due process analysis validates too much by arguing that the tradition supporting a challenged practice must be one of "unchallenged validity," and that such a tradition can trump only "ambiguous constitutional text."116 Thus, according to Justice Scalia, Brown was correctly decided because: (1) "in the 19th century the principle of 'separate-but-equal' had been vigorously opposed on constitutional grounds, litigated up to this Court, and upheld only over the dissent of [Justice Harlan,] one of our historically most respected Justices"; ${ }^{117}$ and (2) the Thirteenth and Fourteenth Amend-

racial discrimination which it was the object of the Fourteenth Amendment to eliminate." (quoting Korematsu v. United States, 323 U.S. 214, 216 (1944))).

11 See generally Railway Express Agency v. New York, 336 U.S. 106, 110 (1949) (explaining that so long as the classification at issue is not a suspect or quasi-suspect class, it must bear only a "relation to the purpose for which it is made" in order to withstand scrutiny under the Equal Protection Clause).

${ }^{114}$ See Buck, 274 U.S. at 207 ("It is better for all the world, if instead of waiting to execute degenerate offspring for crime, or to let them starve for their imbecility, society can prevent those who are manifestly unfit from continuing their kind."). The policy justifications have not run dry in the past seventy years. See, e.g., Beverly Horsburgh, Schrödinger's Cat, Eugenics, and the Compulsory Sterilization of Welfare Mothers, 17 CARDOZO L. REV. 531, 535 (1996) (noting one study's finding that "ninety-seven percent of obstetricians favor the sterilization of unmarried welfare mothers").

The equal protection argument $I$ sketch in the text is drawn from DANIEL $A$. FARBER ET AL., CASES AND MATERIALS ON CONSTITUTIONAL LAW 404-06 (1993) (discussing the likely result in Buck under modern equal protection jurisprudence). Since Buck, the Court has invalidated one state compulsory-sterilization statute on statute-specific equal protection grounds. See Skinner v. Oklahoma ex rel. Williamson, 316 U.S. 535 (1942). The Skinner Court did not overrule Buck, however. See id. at 542 (distinguishing Buck).

115 The right to procreate arguably was established as fundamental in Skinner. See Skinner, 316 U.S. at 541 ("Marriage and procreation are fundamental to the very existence and survival of the race."); see also Washington v. Glucksberg, $117 \mathrm{~S}$. C. 2258, 2267 (1997) (citing Skinner as establishing the right to procreate as fundamental); Recent Legislation, 110 HARV. L. REV. 799 (1997) (discussing constitutional issues surrounding compulsory sterilization). However, this does not change the fact that the specificity approach approves of involuntary sterilization after no more analysis than a bit of historical research.

${ }^{116}$ Rutan v. Republican Party, 497 U.S. 62, 95-96 n.1 (1990) (Scalia, J., dissenting).

${ }_{117}$ Id. (Scalia, J., dissenting) (citing Plessy v. Ferguson, 163 U.S. 537, 555-56 (1896) (Harlan, J., dissenting)). 
ments "leave[] no room for doubt that laws treating people differently because of their race are invalid."118

The problem with Justice Scalia's qualifications, however, is that they reintroduce the inevitable subjectivity that the specificity approach purports to banish from constitutional decisionmaking. Asserting the putative validity of a counter-traditional outcome by declaring certain clauses of the Constitution "unambiguous" merely begs the question of constitutionality. It also seems counterintuitive to allow the due process inquiry to turn on whether a practice has been unsuccessfully challenged in the past. Under this aspect of the specificity approach, perhaps the next three or four Egelhofflike challenges will successfully chip away at the tradition of excluding intoxication evidence so as to allow the fifth to succeed. ${ }^{119}$

Moreover, Justice Scalia does not faithfully apply these qualifications of his specificity approach. In Egelhoff, for example, Justice Scalia proceeded under the specificity approach, despite both the ambiguity of the Due Process Clause on the issue of excluding intoxication evidence offered to negate mens rea, and the fact that the common law tradition of prohibiting intoxication evidence to negate mens rea was clearly "challenged" by both common law scholars and common law courts. ${ }^{120}$

\section{c. The Specificity Approach and Evidentiary Proscriptions}

The specificity approach and reliagce on tradition has been eschewed in other cases involving procedural due process challenges to evidentiary proscriptions. In Crane $v$. Kentucky, the Court held that excluding evidence challenging the credibility of the defendant's confession violated the defendant's "fundamental [due process] right to a fair opportunity to present a defense." ${ }^{121}$ The state court in Crane held that the excluded evidence bore only on the voluntariness of the confession, a legal issue already determined by the court, and not on

${ }^{118}$ Id. at 95 (Scalia, J., dissenting).

119 The requirement that a tradition be one of "unchallenged acceptance" in order to be insulated from a due process challenge seems to be rooted in the defense of tradition's role in constitutional decisionmaking offered by Justice Kennedy: "Historical acceptance of legal institutions serves to validate them not because history provides the most convenient rule of decision but because we have confidence that a longaccepted legal institution would not have survived if it rested upon procedures found to be either irrational or unfair." Pacific Mut. Life Ins. Co. v. Haslip, 499 U.S. 1, 40 (1991) (Kennedy, J., concurring in the judgment).

${ }^{120}$ See supra Part II.A.

${ }^{121} 476$ U.S. 683,687 (1986). 
the confession's credibility. ${ }^{122}$ A unanimous Supreme Court did not inquire into the common law treatment of confession evidence, nor did it rely on nineteenth-century state evidentiary practices. Instead, the Court emphasized: (1) "the common-sense understanding that the circumstances surrounding the taking of a confession can be highly relevant to the two separate inquiries" of voluntariness and credibility; ${ }^{123}$ and (2) the unfairness to the defendant that would result from excluding the evidence. ${ }^{124}$

The Court has taken a similar approach in its Sixth Amendment decisions involving evidentiary proscriptions. For example, in Taylor v. Illinois, ${ }^{125}$ the Court held that the Compulsory Process Clause of the Sixth Amendment, made applicable to the states through the Fourteenth Amendment, ${ }^{126}$ confers upon a criminal defendant a fundamental right to present witnesses in his defense. ${ }^{127}$ At issue in Taylor was the constitutionality of a discovery sanction that excluded the trial testimony of an undisclosed defense witness. ${ }^{128}$ To determine the breadth of the defendant's right (and, thus, the extent to which it could be curtailed consistent with due process), the Court did not inquire into how, if at all, the common law treated eleventh-hour testimony. Rather, the Court weighed the prudential concerns of smooth and orderly trial procedures, fairness to both parties in the adversary system, and the public interest in the full disclosure of crucial facts to conclude that the Compulsory Process Clause does not create an absolute bar to such an evidentiary proscription. ${ }^{129}$

${ }^{122}$ See id. at $686-87$ (setting forth the state court's assertion that there was no error in excluding testimony about the circumstances of the confession "[b]ecause the ... testimony ... pertained only to the voluntariness question").

${ }^{123}$ Id. at $688-89$.

${ }^{124}$ See id. at 690 (concluding "that the blanket exclusion of proffered testimony about the circumstances of [defendant's] confession deprived him of a fair trial").

125484 U.S. 400 (1988).

${ }^{126}$ See Washington v. Texas, 388 U.S. 14, 18 (1967) ("The right of an accused to have compulsory process for obtaining witnesses in his favor stands on no lesser footing than the other Sixth Amendment rights that we have previously held applicable to the States.").

${ }^{127}$ See Taylor, 484 U.S. at 408-09 (noting that " [f] ew rights are more fundamental than that of an accused to present witnesses in his own defense").

${ }^{123}$ See id. at 401-02 ("The question presented is whether that refusal [to allow the undisclosed witness to testify] violated the petitioner's constitutional right to obtain the testimony of favorable witnesses.").

129 See id. at 411-12 ("The trial process would be a shambles if either party had an absolute right to control the time and content of his witnesses' testimony."). 


\section{d. An Alternative Approach: The Right to Present Competent, Reliable Evidence in Defense to a Criminal Charge}

I have argued above that the plurality's historical survey in Egelhoff should not be the final word on whether Montana's exclusionary statute violates due process. An alternative approach, urged by the Egelhoff dissenters, is based on a line of cases establishing a defendant's due process right to present a defense. In Chambers $v$. Mississippi, the Court articulated that right: "The right of an accused in a criminal trial to due process is, in essence, the right to a fair opportunity to defend against the State's accusations." ${ }^{130}$ A "fair opportunity," of course, does not mean an unlimited opportunity. The Chambers Court made clear that criminal defendants "must comply with established rules of procedure and evidence designed to assure both fairness and reliability in the ascertainment of guilt and innocence."131 Due to the prejudicial nature of evidentiary proscriptions, however, the asserted interests of the state in utilizing such rules and procedures must be "closely examined." 132

In Crane v. Kentucky, the Court clarified the notion of "fair opportunity." dence relating to the circumstances of a murder defendant's confession. The Court reiterated the State's legitimate and overriding interest in "exclud[ing] evidence through the application of evidentiary rules that ... serve the interests of fairness and reliability, "134 but concluded that the "blanket exclusion" at issue in Crane did not serve these interests. ${ }^{135}$ In essence, the Crane Court held that evidentiary proscriptions that do not serve valid state interests deprive a criminal defendant of a fair trial, and, therefore, violate the Due Process Clause. According to the Court, the fair opportunity to defend against the State's accusations

would be an empty one if the State were permitted to exclude competent, reliable evidence... when such evidence is central to the defendant's claim of innocence. In the absence of any valid state justification, exclusion of this kind of exculpatory evidence deprives a defendant of

\footnotetext{
${ }^{130} 410$ U.S. 284, 294 (1973).

131 Id. at 302.

132 Id. at 295 .

133476 U.S. 683 (1986).

134 Id. at 690.

135 Id. at 690-91.
} 
the basic right to have the prosecutor's case encounter and "survive the crucible of meaningful adversarial testing." 186

The plurality in Egelhoff emphasized the error of the Supreme Court of Montana's overstatement that criminal defendants have a "due process right to present and have considered by the jury all relevant evidence to rebut the State's evidence on all elements of the offense charged." ${ }^{\prime 137}$ The plurality correctly noted that exclusion is proper if the evidence is incompetent, privileged, or unreliable, or if its probative value is substantially outweighed by the danger of unfair prejudice. ${ }^{138}$ These bases for exclusion, however, are derivative of the state's valid interest in assuring fairness and reliability in the criminal process. ${ }^{139}$ The central question in Egelhoff should have been whether Montana's exclusionary statute is based on these interests. If it is, then it conforms to due process requirements. If, however, the statute is based on other interests, then Montana has overstepped the bounds of permissible justification for limiting a defendant's presentation of exculpatory evidence.

The plurality maintained that a state's pursuit of "legitimate penological goals" may justify evidentiary proscriptions. ${ }^{140}$ The plurality marshaled a myriad of policy goals that purportedly are served by rendering intoxication irrelevant to criminal liability: deterrence of irresponsible drunken behavior, incapacitation, and the reaffirmation of "society's moral perception that one who has voluntarily impaired his own faculties should be responsible for the consequences."141 Additionally, the plurality noted one other justification that "makes some sense": intoxication evidence may be misleading because juries may operate under a cultural misperception that intoxication neces-

\footnotetext{
${ }^{136} I d$. (quoting U.S. v. Cronic, 466 U.S. 648,656 (1984)).

137 Egelhoff, 116 S. Ct. at 2016, 2017 (quoting State v. Egelhoff, 900 P.2d at 266).

${ }^{138}$ See id. at 2017.

${ }^{199}$ Justice O'Connor noted:

To be sure, the right to present evidence is not limitless; for example, it does not permit the defendant to introduce any and all evidence he believes might work in his favor, nor does it generally invalidate the operation of testimonial privileges. Nevertheless, "an essential component of procedural fairness is an opportunity to be heard. That opportunity would be an empty one if the State were permitted to exclude competent, reliable evidence" that is essential to the accused's defense.
}

$I d$. at 2027 (O'Connor, J., dissenting) (citations omitted) (quoting Crane, 476 U.S. at $690)$.
${ }^{140}$ Id. at 2021 n.5.
${ }^{111} \mathrm{Id}$. at 2020. 
sarily causes people to be violent. ${ }^{142}$ According to the plurality, this misperception, coupled with evidence of intoxication, may render juries "too quick to accept the claim that the defendant was biologically incapable of forming the requisite mens rea." ${ }^{143}$

As Chambers and Crane make clear, there is a significant difference between a policy goal that might inform a state's substantive criminal law and an interest in fairness and reliability that might support an evidentiary proscription. Undoubtedly, the policy goals discussed by the plurality are laudable and are properly the concern of the state. The question is whether the state may assert these goals by restricting a defendant's right to present a defense rather than by modifying its substantive law. Chambers and Crane certainly imply that a state must effectuate such criminalization judgments through its substantive criminal law.

Why should this be the case? If the end (here, holding intoxicated wrongdoers criminally liable to the same extent as sober offenders) is permissible, why are the means to that end important? What harm is done when the state effectuates its policy choices by limiting the rights of criminal defendants? First and foremost, as discussed above, the Court has sanctioned a state's exclusion of exculpatory evidence only where the state seeks to advance the interests of fairness and reliability in the criminal process. ${ }^{144}$ Extending this rationale to cover the effectuation of criminalization judgments is not supported by the Court's precedents. It is also fundamentally unfair. This unfairness is demonstrated by examining Montana's proffered justification for its exclusionary statute:

Montana is unwilling to allow those who commit serious crimes to benefit from a voluntarily assumed condition.... In addition, the societal consequences from intoxication are so detrimental that, as to the existence of a required mental state, the intoxicated person should be denied any exculpatory excuse based on the mere fact of voluntary intoxication.... Allowing a defendant to exculpate his conduct by means of a self-induced condition flies in the face of the principle of personal accountability forming the foundation of all law.... [Montana's exclusionary statute] ... depriv[es] a voluntarily intoxicated person of the ability to negative the intent element of a crime on the basis of his in-

142 See id. at 2021.

143 Id.

${ }^{144}$ See, e.g., Crane, 476 U.S. at 690 ("[W]e have never questioned the power of States to exclude evidence through the application of evidentiary rules that themselves serve the interests of fairness and reliability-even if the defendant would prefer to see that evidence admitted."). 
toxication-i.e., by depriving him of the ability to use one form of culpable conduct to eliminate responsibility for another. ${ }^{145}$

Nowhere does Montana suggest that intoxication evidence is misleading, unreliable, or otherwise unfair when it is offered to negate mens rea. In fact, Montana readily acknowledges the probative value and reliability of intoxication evidence when offered to negate mens rea: its exclusionary statute allows introduction of such evidence to negate mens rea in cases of involuntary intoxication. ${ }^{146}$ This double standard demonstrates the unfairness of Montana's exclusionary statute. Montana's actual state interest, therefore, is "to ensure that even a defendant who lacked the required mental-state element-and is therefore not guilty-is nevertheless convicted of the offense. ${ }^{\text {147 }}$ Put differently, Montana's interest is to convict Egelhoff of negligent deliberate homicide. ${ }^{148}$ Such an interest is illegitimate.

The policy goals that Montana articulates, ${ }^{149}$ and that the Egelhoff plurality reiterated, ${ }^{150}$ are perfectly legitimate goals that might inform a criminalization judgment, but they are not goals that validly may be asserted against a defendant's right to introduce exculpatory evidence to defend against a charge that requires, in part, the existence of a particular mental state.

The only argument for the exclusion of intoxication evidence on reliability grounds is the plurality's argument that such evidence may mislead and confuse juries. ${ }^{151}$ This putative justification is based on psychological studies that suggest that the connection between intoxication and criminal conduct is as much cultural as pharmacologi$\mathrm{cal}^{152}$ The argument is that people have learned beliefs that intoxication causes criminal conduct, and that these beliefs lead intoxicated

145 Brief for Petitioner [State of Montana] at 18-19, Egelhoff, (No. 95-566).

146 See MONT. CODE ANN. § 45-2-203 (1997).

${ }^{147}$ Egelhoff, 116 S. Ct. at 2028 (O'Connor, J., dissenting).

148 See supra Part III.C.1.b.

149 See supra note 140 and accompanying text.

150 See Egelhoff, 116 S. Ct. at 2020-21.

151 See supra notes 142-43 and accompanying text.

152 See James J. Collins, Suggested Explanatory Frameworks to Clarify the Alcohol Use/Violence Relationship, 15 CONTEMP. DRUG PROBS. 107, 109 (1988) (noting "the relevance of psychological, social and cultural factors" in addition to the physiological factor); Barbara Critchlow, The Powers of John Barleycorn: Beliefs About the Effects of Alcohol on Social Behavior, 41 AM. PSYCHOLOGIST 751, 751 (1986) (refusing to ignore the pharmacological effects of alcohol, yet focusing on the "social learning/placebo effect model of alcohol effects"). 
people to commit crimes ${ }^{153}$ and lead juries to conclude that intoxicated wrongdoers are incapable of forming the mens rea of the offense charged. ${ }^{154}$ Assuming the latter conclusion is incorrect, intoxication evidence should be kept from juries because it is misleading.

Given the equivocal support this argument receives from the plurality, ${ }^{155}$ and Justice Scalia's elsewhere-proclaimed skepticism toward basing law on psychology, ${ }^{156}$ it is questionable whether the plurality gives much credence to this argument. This argument, however, is the only justification based on the legitimate state interest of assuring the fairness and reliability of criminal proceedings. Regardless of the validity of the argument, Montana clearly did not offer it as a justification for its exclusionary statute. ${ }^{157}$

\section{e. Cutting Conceptual Cormers and Subjective Perceptions of Unfaimess}

Independent of the due process argument made above, there are two other reasons to question the legitimacy of implementing criminalization judgments through evidentiary proscriptions that curb a defendant's right to present reliable exculpatory evidence.

First, inferring modifications of the substantive criminal law from rules about the admissibility of evidence obscures the underlying criminalization judgment, thereby insulating it from political debate. Reading Montana's exclusionary statute as a redefinition of the State's substantive criminal law amounts, as I argue above, to the punishment of some negligent homicides as deliberate homicides. ${ }^{158}$ To infer such a significant change in the substantive criminal law from an evidentiary proscription seems odd, especially considering the legislature's retention of the subjective mens rea element of deliberate homicide. ${ }^{159}$ Montana's brief to the Supreme Court in Egelhoff relied

${ }^{15 s}$ See Collins, supra note 152, at 115; Critchlow, supra note 152, at 754-55.

154 See Egelhoff, 116 S. Ct. at 2021.

${ }^{155}$ See id. (characterizing the misleading-evidence rationale as making "some sense").

${ }^{155}$ See Lee v. Weisman, 505 U.S. 577, 636 (1992) (Scalia, J., dissenting) ("[I]nterior decorating is a rock-hard science compared to psychology practiced by [judges]. A few citations of '[ $\mathrm{r}$ ] esearch in psychology' that have no particular bearing upon the precise issue here cannot disguise the fact that the Court has gone beyond the realm where judges know what they are doing." (alteration in original) (citation omitted)).

${ }^{157}$ See Egelhoff, 116 S. Ct. at 2028-29 (O'Connor, J., dissenting).

158 See supra Part III.C.1.b.

${ }^{139}$ See Egelhoff, 116 S. Ct. at 2035 (Breyer, J., dissenting) ("If the legislature wanted to equate voluntary intoxication, knowledge, and purpose, why would it not write a statute that plainly says so ... . ?"). 
on the language of the exclusionary statute ${ }^{160}$ to argue that the Montana legislature intended to redefine the substantive criminal law: "The first clause represents a general statement of legislative intent to remove intoxication as a ground for negativing a defendant's criminal responsibility." 161 This claim is dubious, though, given that the legislature plainly thought that intoxication evidence itself was sufficiently probative of mental state to exculpate a defendant who was involuntarily in toxicated. ${ }^{162}$

Rather than evidencing a legislative intent to redefine the substantive criminal law, Montana's exclusionary statute appears to be a vague affirmation of the social judgment that intoxicated wrongdoers should be kept from asserting admittedly exculpatory evidence (i.e., voluntary intoxication) because that evidence itself indicates a blameworthy character. The crucial point here is that this social judgment bears only on the use of intoxication as an affirmative defense, not as a failure of proof claim. A legislature cannot make a social judgment as to what facts are pharmacologically relevant to the formation of a requisite mental state. Properly understood, Montana's exclusionary statute is intended only to prevent intoxicated wrongdoers from being ipso facto excused from criminal liability. This is very different from asserting that intoxication is irrelevant to the question of mens rea.

The Court's willingness to infer a redefinition of a state's substantive law relieves the legislature of its obligation to consider these issues. After Egelhoff, the legislature need not consider the constitutional differences between banning an affirmative defense and limiting a failure of proof claim. The legislature need not sort out exactly what it thinks is wrong about an intoxicated wrongdoer being acquitted of a crime; the fiction of an "implicit redefinition" replaces candid consideration of criminalization judgments. The result is to diminish the likelihood of full and open legislative debate on the nature of criminalization judgments and the due process concerns they implicate.

The second reason to question the legitimacy of implementing criminalization judgments through evidentiary proscriptions is that couching modifications of the substantive criminal law in rules about

100 "A person who is in an intoxicated condition is criminally responsible for his conduct...." MONT. CODE ANN. $\$ 45-2-203$ (1997).

${ }^{161}$ Reply Brief for Petitioner [State of Montana] at 16 (No. 95-566). fense).

162 See MONT. CODE ANN. $§ 45-2-203$ (recognizing involuntary intoxication as a de- 
the admissibility of evidence entails a significant danger of increasing subjective perceptions of unfairness among criminal defendants. A defendant is likely to perceive unfairness if his jury is instructed that, on the one hand, the State must prove purpose or knowledge beyond a reasonable doubt, but on the other hand, the jury must not consider his intoxication as challenging the State's proof. If the criminalization judgment were effected through a redefinition of the substantive criminal law rather than through an evidentiary proscription, the State, presumably, would be required to produce no evidence of the subjective mental state of an intoxicated wrongdoer at trial. ${ }^{163}$ Although a rule of this type sounds rather harsh, for the intoxicated wrongdoer who otherwise would be exculpated by intoxication evidence, it is no harsher, and is much more forthright, than simply preventing him from presenting his only relevant rebuttal evidence.

Aside from general fairness considerations, why might one care about a criminal defendant's perception of unfairness? One reason might be the prevention of recidivism. A defendant who feels he has been treated unfairly by the criminal justice system may be more likely to commit crimes in the future. This is the conclusion of "defiance theory." ${ }^{\text {"164 }}$ According to defiance theorists, the convict who sincerely feels he has been unfairly treated is not shamed by the imposition of a criminal sanction; rather, he feels stigmatized by it. ${ }^{165}$ This reaction eviscerates the deterrent effect of punishment, and may in fact lead to increased recidivism. ${ }^{166}$

A second reason to limit a criminal defendant's perception of unfairness is to prevent wasteful appeals. Here, the presumption is that many criminal appeals are motivated by perceived procedural unfairness rather than by protestations of innocence. Although this is an

\footnotetext{
${ }^{165}$ This would depend, of course, on the exact nature of the substantive statute.

${ }^{164}$ See, e.g., Lawrence W. Sherman, Defiance, Deterrence, and Irrelevance, 30 J. RES. CRIME \& DELINQ. 445, 459-61 (1993) (summarizing defiance theory).

165 See id. The stigmatizing effect of perceived unfairness has led some commentators to use defiance theory to explain racial disparities in the criminal justice system. See, e.g., Katheryn K Russell, The Racial Hoax as Crime: The Law as Affirmation, 71 IND. L.J. 593, 607-11 (1996) (discussing defiance theory to explain the nexus between race and crime).

${ }^{166}$ See John Braithwatte, Crime, Shame and Reintegration 177-82 (1989) (arguing that successfully shaming an offender is integral to the moral education and deterrent qualities of criminal punishment); Sherman, supra note 164, at 461 (noting that "the unfair stigmatizing sanction will increase... future rates of offending"). See generally TOM R. TYLER, WHY PEOPLE OBEY THE LAW (1990) (drawing a causal connection between perceptions of fairness, judgments of legitimacy, and future patterns of compliance with the law).
} 
empirical premise that would be difficult to verify, it seems safe to assume that limiting perceptions of unfairness would at least marginally affect the rate of wasteful appeals. This may be especially true in cases like Egelhoff, where the perceived unfairness is the arbitrary limitation of one's defense. ${ }^{167}$

Another reason to care about perceptions of unfairness is that the Supreme Court has recognized limiting such perceptions as important. In the context of issues ranging from race-based peremptory challenges, ${ }^{168}$ to the right to private counsel, ${ }^{169}$ to the right to a hearing before being branded a Communist, ${ }^{170}$ the Supreme Court has

${ }^{167}$ See, e.g., Thomas Gilson, Federal Sentencing Guidelines-The Requirement of Notice for Upward Departure, 82 J. CRIM. L. \& CRIMINOLOGY 1029, 1051-52 (1992) (arguing that conditioning an upward departure from the sentencing guidelines on whether the defendant testifies at trial is likely to result in an appeal based on the perceived unfairness of limiting the presentation of a defense).

${ }^{163}$ As noted by Justice Kennedy:

The jury acts as a vital check against the wrongful exercise of power by the State and its prosecutors. The intrusion of racial discrimination into the jury selection process damages both the fact and the perception of this guarantee.... Active discrimination by a prosecutor during this process ... invites cynicism respecting the jury's neutrality and its obligation to adhere to the law.

$\cdots$

The purpose of the jury system is to impress upon the criminal defendant and the community as a whole that a verdict of conviction or acquittal is given in accordance with the law by persons who are fair. The verdict will not be accepted or understood in these terms if the jury is chosen by unlawful means at the outset.

Powers v. Ohio, 499 U.S. 400, 411-13 (1991) (citations omitted).

${ }^{169}$ In dissent, Justice Blackmun wrote:

Not only are decisions crucial to the defendant's liberty placed in counsel's hands, but the defendant's perception of the fairness of the process, and his willingness to acquiesce in its results, depend upon his confidence in his counsel's dedication, loyalty, and ability. When the Government insists upon the right to choose the defendant's counsel for him, that relationship of trust is undermined: counsel is too readily perceived as the Government's agent rather than his own.

Caplin \& Drysdale, Chartered v. United States, 491 U.S. 617, 645 (1989) (Blackmun, J., dissenting) (citations omitted); see also Faretta v. California, 422 U.S. 806, 834 (1975) (discussing the right of a criminal defendant to represent himself, and noting that "[ $t$ ] o force a lawyer on a defendant can only lead him to believe that the law contrives against him").

${ }^{170}$ Justice Frankfurter found that:

The validity and moral authority of a conclusion largely depend on the mode by which it was reached. .. . No better instrument has been devised for arriving at truth than to give a person in jeopardy of serious loss notice of the case against him and opportunity to meet it. Nor has a better way been found for generating the feeling, so important to a popular government, that justice has been done. 
recognized that perceptions of unfairness undermine the legitimacy of the criminal justice system. In fact, a criminal defendant's perception of unfairness has been considered an injury in fact sufficient to confer Article III standing. ${ }^{171}$

\section{EGELHOFFAND OTHER STATES' EXCLUSIONARY SCHEMES}

As noted above, eleven states (in addition to Montana) currently prohibit the use of intoxication evidence to negate mens rea. ${ }^{172}$ These evidentiary proscriptions have been made law in three ways: by specific statutory provision; by judicial interpretation of a general statutory provision; and by judicial decision. Because Egelhoff s holding relied on Justice Ginsburg's determination that Montana's exclusionary statute redefined the state's substantive criminal law, ${ }^{173}$ the constitutionality of other states' exclusionary schemes remains an open question. This Part briefly discusses some of these other exclusionary schemes in light of Egelhoff and the foregoing critique of the reasoning in that case. I do not intend to explore fully the constitutionality of these schemes. Rather, this Part clarifies the limits of the Court's holding in Egelhoff and suggests that the concerns raised by Egelhoff are implicated to an even greater extent by some other states' exclusionary schemes. This analysis is particularly relevant as state legislatures and lower courts, both federal and state, continue to rely on Egelhoff to enact and review similar exclusionary schemes. ${ }^{174}$

\section{A. Proscription by Specific Statutory Provision}

Arizona, Hawaii, Idaho, Indiana, Missouri, and Pennsylvania prohibit by specific statutory provision the use of voluntary intoxication evidence to negate mens rea. ${ }^{175}$ Each of these exclusionary schemes,

Joint Anti-Fascist Refugee Comm. v. McGrath, 341 U.S. 123, 171-72 (1951) (Frankfurter, J., concurring).

${ }^{171}$ See Powers, 499 U.S. at 411 ("The discriminatory use of peremptory challenges by the prosecution causes a defendant cognizable injury ... because racial discrimination in the selection of jurors 'casts doubt on the integrity of the judicial process' and places the fairness of a criminal proceeding in doubt." (quoting Rose v. Mitchell, 443 U.S. 545, $556(1979))$ ).

${ }^{172}$ See supra text accompanying notes $29-30$.

${ }^{173}$ See supra text accompanying notes 57-58.

${ }^{174}$ See supra notes $30,82$.

${ }^{175}$ See ARIZ. REV. STAT. $\$ 13-503$ (Supp. 1997) ("Voluntary intoxication] is not a defense for any criminal act or requisite state of mind."); HAw. REV. STAT. $\$ 702-$ 230(2) (1993) ("Evidence of self-induced intoxication of the defendant is not admissi- 
with the probable exception of Hawaii's, is similar enough to the Montana statute upheld in Egelhoff to be deemed constitutional under that decision. ${ }^{176}$ Although Egelhoff maintains that an exclusionary statute "regulating solely the admissibility of evidence at trial" is unconstitutional, ${ }^{177}$ Justice Ginsburg's expansive reading of the Montana statute in Egelhoff as accomplishing an implicit redefinition of the substantive offense ${ }^{178}$ assures that the statutes in these states fall safely within Egelhoffs holding.

Hawaii's exclusionary statute is unique. Section 702-230(2) of the Hawaii Revised Statutes provides:

Evidence of self-induced intoxication of the defendant is admissible to prove or negative conduct or to prove state of mind sufficient to establish an element of an offense. Evidence of self-induced intoxication of the defendant is not admissible to negative the state of mind sufficient to establish an element of the offense. ${ }^{179}$.

Regarding intoxication evidence, Hawaii prosecutors can have their cake and eat it too. Hawaii's exclusionary statute authorizes the State to use intoxication evidence to prove mens rea (presumably in the context of negligence offenses), but prohibits the defendant from using it to negate mens rea.

ble to negative the state of mind sufficient to establish an element of the offense."); IDAHO CODE $\$ 18-116$ (1997) ("[A]n intoxicated condition ... may not be taken into consideration in determining the existence of a mental state which is an element of the offense ...."); IND. CODE ANN. $\S 35-41-2-5$ (West Supp. 1997) ("Intoxication ... may not be taken into consideration in determining the existence of a mental state that is an element of the offense ...."); MO. REV. STAT. \$ 562.076(3) (Supp. 1997) ("Evidence that a person was in a voluntarily intoxicated or drugged condition may be admissible when otherwise relevant on issues of conduct but in no event shall it be admissible for the purpose of negating a mental state which is an element of the offense."); 18 PA. CONS. STAT. ANN. \$ 308 (West 1983) ("[V]oluntary intoxication [is not] a defense to a criminal charge, nor may evidence of such condition[] be introduced to negative the element of intent of the offense, except... whenever it is relevant to reduce murder from a higher degree to a lower degree of murder.").

${ }^{176}$ Compare ARIZ. REV. STAT. $\$ 13-503$ (Supp. 1997) (precluding use of evidence of voluntary intoxication to negative requisite mental state), IDAHO CODE § 18-116 (Supp. 1997) (same), IND. CODE ANN. $\$ 35-41-25$ (West Supp. 1997) (same), MO. REV. STAT. $§ 562.076$ (3) (Supp. 1997) (same), and 18 PA. CONS. STAT. ANN. § 308 (West 1983) (same), with MONT. CODE ANN. § 45-2-203 (1997) (same).

177 Egelhoff, 116 S. Ct. at 2024 (Ginsburg, J., concurring in the judgment).

${ }^{178}$ See id. (Ginsburg, J., concurring in the judgment) ("Comprehended as a measure redefining mens rea, $\S 45-2-203$ encounters no constitutional shoal. States enjoy wide latitude in defining the elements of criminal offenses ....").

${ }^{179}$ HAW. REV. STAT. \$ 702-230(2) (1993) (emphasis added). 
Central to Justice Ginsburg's Egelhoff concurrence was the fact, urged by Montana and amici, that Montana's exclusionary statute "'extract[s] the entire subject of voluntary intoxication from the mens rea inquiry,' thereby rendering evidence of voluntary intoxication logically irrelevant to proof of the requisite mental state." ${ }^{\prime 10}$ No such extraction occurs under Hawaii's exclusionary statute. Instead, the plain language of Hawaii's exclusionary statute deems intoxication evidence relevant to the mens rea inquiry. ${ }^{181}$ In light of this legislative determination, the only plausible explanation for Hawaii's prohibition on defendant-offered intoxication evidence is to improve the State's chances of winning a conviction. ${ }^{182}$ As argued above, this is an illegitimate purpose for excluding relevant exculpatory evidence. ${ }^{189}$

Furthermore, the operation of Hawaii's exclusionary statute demonstrates a flaw in Justice Ginsburg's reasoning in Egelhoff. According to Justice Ginsburg, a state may not exclude intoxication evidence unless it redefines its substantive law by extracting intoxication evidence from the entire mens rea inquiry. ${ }^{184}$ Hawaii's statute plainly does not do this. Therefore, Justice Ginsburg presumably would distinguish Hawaii's statute from Montana's, concluding that the former is an unconstitutional evidentiary proscription. This is problematic because, as discussed below, the operative effect of the Montana and Hawaii statutes is the same.

On its face, Hawaii's statute seems less fair to intoxicated wrongdoers than does Montana's; Montana's statute prohibits both the State and the defendant from offering intoxication evidence on the issue of mens rea. However, Hawaii's exclusionary statute is less fair than Montana's only in its operation over the run of cases-it allows intoxication evidence to prove mens rea in one case and prohibits it from negating mens rea in another. From the perspective of any particular defendant, Hawaii's statute will operate in precisely the same

${ }^{180}$ Egelhoff, 116 S. Ct. at 2024 (Ginsburg, J., concurring in the judgment) (quoting Reply Brief for Petitioner [State of Montana] at 2 (No. 95-566)).

'See supra note 179 and accompanying text.

${ }^{182}$ Cf. supra notes $146-48$ and accompanying text. It should be noted that this reading of Hawaii's exclusionary statute is contrary to that of the state's high court. In State v. Souza, 813 P.2d 1384, 1386 (Haw. 1991), the Supreme Court of Hawaii held the statute constitutional based on its determination that the statute redefines the mens rea element of all state crimes. The court's one-page analysis of the statute's constitutionality does not address the fact that the statute permits the introduction of intoxication evidence to prove mens rea. Given the opinions in Egelhoff, it is safe to assume that the Souza court's analysis is incomplete, to say the least.

${ }^{183}$ See supra Part III.C.2.d.

${ }^{184}$ See Egelhoff, 116 S. Ct. at 2024 (Ginsburg, J., concurring in the judgment). 
manner as Montana's; the exclusionary effect of the two statutes is the same. No single defendant will experience the unfairness of Hawaii's double standard for intoxication evidence because in no single case will a defendant's intoxication evidence be barred and the prosecution's admitted. ${ }^{185}$

The unfairness of Hawaii's exclusionary statute stems from the unequal manner in which intoxication evidence is treatedadmissible when offered by the State and inadmissible when offered by the defendant. Such a claim, if cognizable, falls under the Equal Protection Clause, not the Due Process Clause. Therefore, the due process analysis does not turn on whether or not intoxication evidence is extracted from the entire mens rea inquiry.

How does this undermine Justice Ginsburg's reasoning in Egelhoff? Because Montana's implicit redefinition and Hawaii's evidentiary proscription operate identically to curtail due process from the perspective of any individual defendant, Justice Ginsburg erred in positing a constitutionally redeeming distinction between an implicit redefinition and an evidentiary proscription. Both readings of Montana's exclusionary statute violate due process in precisely the same way: They exclude evidence that is admittedly relevant to the subjective mens rea element of the charged offense. ${ }^{186}$

\section{B. Proscription by Judicial Interpretation of a General Statutory Provision}

Courts in Arkansas, Delaware, Georgia, and Texas have interpreted statutes providing or implying that intoxication is "no defense" to a criminal charge as meaning that the jury may not consider in-

${ }^{185}$ To understand this, one must think about the types of cases in which Hawaii's statute is likely to be invoked. The defendant will seek to introduce intoxication evidence only in prosecutions of subjective mens rea offenses. The defendant has no use for intoxication evidence in prosecutions of negligence offenses, because being intoxicated is itself negligent. The State, however, is likely to introduce intoxication evidence only in prosecutions of negligence offenses, because its use in subjective mens rea offenses is logically mitigatory.

Therefore, in all prosecutions for subjective mens rea offenses, the defendant is prohibited from introducing intoxication evidence on the issue of mens rea and the State has no reason to introduce such evidence. This is precisely the operative effect of Montana's exclusionary statute.

${ }^{286}$ To insist that intoxication evidence is irrelevant under Montana's "redefinition" of its substantive law is to adopt the nonsensical position that Montana has established a crime of negligent deliberate homicide. See supra Part III.C.1.b. It is important to note that not all redefinitions would operate identically to evidentiary proscriptions, and therefore violate due process. For instance, a redefinition that establishes an objective mens rea element would not violate due process. See infra Part V. 
toxication evidence to negate mens rea. ${ }^{187}$ Does a statute that provides that intoxication "is not a defense" merely prohibit the defendant from asserting intoxication evidence as an affirmative defense? Or does it also prohibit the defendant from using intoxication evidence to rebut the prosecution's prima facie case?

In Egelhoff, prohibiting the jury from considering intoxication evidence to negate mens rea had specific statutory support. ${ }^{188}$ Even so, the Court held that due process requires that an exclusionary statute effectuate an (at least) implicit redefinition of the state's substantive law. ${ }^{189}$ In the case of general statutory provisions, the link between the statute and the conclusion that intoxication evidence cannot negate mens rea is more tenuous. Given Egelhoffs recognition of implicit redefinitions, however, it does not appear that such a direct link between the statute and the redefinition is necessary to conclude that intoxication evidence is inadmissible to negate mens rea.

The pivotal question in these cases is one of statutory construction. Under Egelhoff, if the interpreting court determines that the legislature has even implicitly redefined the substantive law, there will be no due process violation. Although Egelhoff sets a low due process hurdle, a review of state court cases interpreting general statutory provisions shows that courts' inquiries into statutory meaning and legislative intent have been less than probing.

For instance, when faced with a challenge similar to that raised in Egelhoff, the Texas Court of Criminal Appeals "interpreted" section 8.04 of the Texas Penal Code, which provides that intoxication is no defense to crime, ${ }^{190}$ this way: "Appellant argues that intoxication

${ }^{187}$ See White v. State, 717 S.W.2d 784, 786-88 (Ark. 1986) (interpreting ARK. CODE ANN. $\S 5-2-207$ (Michie 1992), which provides that "[i]ntoxication that is not self-induced is an affirmative defense to a prosecution if [the defendant] lack[ed the] capacity to conform his conduct to the requirements of the law or to appreciate the criminality of his conduct"); Wyant v. State, 519 A.2d 649, 650-60 (Del. 1986) (interpreting DEL. CODE ANN. tit. 11, $\$ 421$ (1994), which provides that "[voluntary intoxication] is no defense to any criminal charge"); Foster v. State, 374 S.E.2d 188, 195-96 (Ga. 1988) (interpreting GA. CODE ANN. § 16-3-4(c) (1996), which provides that "[v]oluntary intoxication shall not be an excuse for any criminal act or omission"); McElroy v. State, 528 S.W.2d 831, 834 (Tex. Crim. App. 1975) (interpreting TEX. PENAL CODE ANN. $\$ 8.04$ (a) (West 1990), which provides that "[v]oluntary intoxication does not constitute a defense to the commission of crime").

189 See MONT. CODE ANN. § 45-2-203 (1997).

${ }^{189}$ See Egelhoff, 116 S. Ct. at 2024 (Ginsburg, J., concurring in the judgment) (noting that the statute at issue could be interpreted as a redefinition of mens rea).

190 See TEX. PENAL CODE ANN. \$ 8.04(a) ("Voluntary intoxication does not constitute a defense to the commission of crime."). 
could bear on the ability to form the intent to commit an act, and the jury should be so instructed. The jury was instructed in accordance with [section 8.04]. No error is shown." ${ }^{\text {191 }}$ Other courts have been considerably more thorough, investigating the legislative history of the general statutory provisions and considering other documentation showing legislative intent. ${ }^{192}$

The point here is not to question the correctness of these decisions, but rather to highlight the dangers that lie in inferring redefinitions of substantive criminal law from general statutory provisions prohibiting intoxication as a "defense." There is frequently insufficient evidence of legislative intent to determine the intended extent of the statutory provision, and at least some courts have been reluctant to engage in anything beyond a cursory interpretation of the general statutes. Given the liberty interests at stake, courts should be particularly wary of interpreting general statutory provisions as sweeping redefinitions of a state's substantive criminal law.

\section{Proscription by Judicial Decision}

In the absence of statutory authority, courts in Mississippi, South Carolina, and Virginia have held that evidence of intoxication cannot negate mens rea. ${ }^{193}$ These judge-made exclusionary schemes operate as straightforward evidentiary proscriptions; in no sense has the legislature redefined the state's substantive criminal law. Therefore, Egelhoff s requirement of a redefinition of a state's substantive law places the constitutionality of these exclusionary schemes in doubt. ${ }^{194}$ To suggest that a court may redefine the state's substantive criminal law and apply the newly redefined offense in the case before it is to forsake the fundamental constitutional principles of separation of pow-

${ }^{191}$ McElroy, 528 S.W.2d at 834.

${ }^{192}$ See, e.g., White, 717 S.W.2d at 786-88 (interpreting section 5-2-207 of the Arkansas Code in light of an "emergency clause" which clarified the intent of the legislature); Wyant, 519 A.2d at 654-59 (interpreting title 21, section 421 of the Deleware Code in light of three previous versions of that statute).

${ }^{193}$ See Lee v. State, 403 So. 2d 132, 134 (Miss. 1981) (holding that voluntary intoxication is no defense even to specific intent crimes); State v. Vaughn, 232 S.E.2d 328, 330-31 (S.C. 1977) ("[V]oluntary intoxication, where it has not produced permanent insanity, is never an excuse for or a defense to crime, regardless of whether the intent involved be general or specific."); Gills v. Commonwealth, 126 S.E. 51, 53-54 (Va. 1925) ("Voluntary drunkenness ... is never an excuse for crime; except, where a party is charged with murder, if it appear that the accused was too drunk to be capable of ... premeditating....").

19 See supra Part III.B.2, C. 
ers $^{195}$ and the prohibition of ex post facto laws. ${ }^{196}$ For present purposes, I will focus not on these constitutional arguments, but rather on the policy arguments against judicially created exclusionary schemes.

Judicially created exclusionary schemes should raise concern because, like judicial recognitions of implicit redefinitions, they insulate criminalization judgments from political debate. ${ }^{197}$ When the judiciary creates an exclusionary scheme without statutory authority, the insulation effect is exacerbated. Courts that institute exclusionary schemes not only suppress the policy debates underlying criminalization judgments, they usurp the criminalization decision from the state legislatures. Legislatures, unlike courts, can employ the powerful mechanisms of affirmative fact gathering, debate, and amendment to reach a criminalization decision. Although it is true that state judiciaries may be politically accountable to some extent, they clearly are institutionally less competent than state legislatures to determine whether or not an offender's intoxication should bear on his criminal liability.

Moreover, courts may not recognize the due process concerns at stake when they promulgate exclusionary schemes. This concern is borne out in Mississippi. Until 1978, Mississippi followed the common law rule that intoxication may negate the mens rea element of

${ }^{195}$ The Constitution of the State of Mississippi, for example, provides that:

The powers of the government of the state of Mississippi shall be divided into three distinct departments, and each of them confided to a separate magistracy, to-wit: those which are legislative to one, those which are judicial to another, and those which are executive to another.

No person or collection of persons, being one or belonging to one of these departments, shall exercise any power properly belonging to either of the others.

MISS. CONST. art. I, $\$ \S 1-2 ;$ see alsoS.C. CONST. art. I., $\$ 8$ ("In the government of this State, the legislative, executive, and judicial powers of the government shall be forever separate and distinct from each other, and no person or persons exercising the functions of one of said departments shall assume or discharge the duties of any other."); VA. CONST. art. I, $\$ 5$ ("[T]he legislative, executive, and judicial departments of the Commonwealth should be separate and disinct....").

${ }^{196}$ See MISs. CoNST. art. III, $\S 16$ (prohibiting ex post facto laws); S.C. CoNST. art I, $\S 4$ (same); VA. CoNST. art I, $\$ 9$ (same).

${ }^{i 97}$ See supra Part III.C.2.e. 
specific intent crimes. ${ }^{198}$ In McDaniel v. State, ${ }^{199}$ decided in 1978, the Supreme Court of Mississippi adopted a new rule:

If a defendant, when sober, is capable of distinguishing between right and wrong, and the defendant voluntarily deprives himself of the ability to distinguish between right and wrong by reason of becoming intoxicated and commits an offense while in that condition, he is criminally responsible for such acts. ${ }^{200}$

In doing so, the court overruled twenty-three of its decisions, dating back to $1844 .^{201}$

Although the McDaniel rule reads as if it was intended to prohibit the affirmative defense of intoxication-induced insanity, ${ }^{202}$ the defendant in McDaniel raised no such defense. According to the court, McDaniel's theory at trial was that he "was so intoxicated he could not form the requisite intent required for the commission of [the offense]. ${ }^{203}$ Instead of treating this as a failure of proof claim offered to rebut the State's prima facie case, the court characterized it as an affirmative defense. ${ }^{204}$ After mischaracterizing McDaniel's failure of proof claim as an affirmative defense, the McDaniel court invoked a familiar, if conclusory, justification for rendering intoxication irrelevant to liability: "[I]f a person casts off the restraints of reason and consciousness by a voluntary act, no wrong is done to him if he is held accountable for any crime which he may commit in that condition. Society is entitled to this protection. ${ }^{205}$ The crucial point here is that by not distinguishing between a failure of proof claim and an affirma-

${ }^{199}$ See, e.g., Edwards v. State, 174 So. 57,58 (Miss. 1937) (holding that a jury instruction that "voluntary drunkenness is no defense to crime" was erroneous with respect to the specific intent crime of larceny).

199356 So. $2 d 1151$ (Miss. 1978).

${ }^{200}$ Id. at 1161 (Sugg, J., specially concurring).

Set See (appending a list of cases overruled by the court's decision).

${ }^{202}$ Compare id., with M'Naghten's Case, 8 Eng. Rep. 718, 722 (H.L. 1843) (articulating the classic test for insanity, which presumes that a defendant is sane until it is clearly proven that he "was labouring under such a defect of reason, from disease of the mind, as not to know the nature and quality of the act he was doing; or, if he did know it, that he did not know he was doing what was wrong").

${ }^{203}$ McDaniel, 356 So. 2d at 1153.

${ }^{204}$ Later decisions by the Supreme Court of Mississippi have confirmed this mischaracterization. See, e.g., Lee v. State, 403 So. 2d 132, 134 (Miss. 1981) (interpreting McDaniel to mean that a defendant, capable of distinguishing between right and wrong when sober, is not entitled to an instruction submitting to the jury his inability to form the specific intent to commit an offense because of his voluntary intoxication at the time the offense was committed").

${ }^{205}$ McDaniel, 356 So. 2d at 1160-61 (Sugg, J., specially concurring). 
tive defense, the court never considered whether excluding McDaniel's intoxication evidence implicated due process rights. ${ }^{206}$

Similar short shrift was given to counterbalancing due process concerns when the Supreme Court of South Carolina, in State $v$. Vaughn, ${ }^{207}$ established a rule prohibiting the introduction of intoxication evidence to negate mens rea. In Vaughn, the defendant was charged with, inter alia, "assault with intent to ravish," a specific intent crime under South Carolina law. ${ }^{208}$ The question for the Supreme Court of South Carolina was whether or not intoxication evidence can negate the specific intent of the crime charged. The court recognized the majority rule that intoxication can negate specific intent, but rejected that approach, stating:

Reason requires that a man who voluntarily renders himself intoxicated be no less responsible for his acts while in such condition. To grant immunity for crimes committed while the perpetrator is in such a voluntary state would not only mean that many offenders would go unpunished but would also transgress the principle of personal accountability which is the bedrock of all law. ${ }^{209}$

Although the Vaughn court articulately stated its vision of what "reason requires," the legislature, as an institution, is better equipped to determine "the principle[s] of personal accountability" than is the judiciary. ${ }^{210}$ As Justice Ginsburg reiterated in Egelhoff, "[st]ates enjoy wide latitude in defining the elements of criminal offenses, particularly when determining 'the extent to which moral culpability should be a prerequisite to conviction of a crime." 211 State courts have never been similarly recognized as fountains of criminal law. Any other rule

${ }^{206}$ The Supreme Court of Mississippi did face this question in a subsequent case, where it determined, much as Justice Ginsburg did in Egelhoff, that the McDaniel rule does not eliminate the prosecution's burden of proving intent. See Lee, 403 So. $2 \mathrm{~d}$ at 134 ("V]oluntary intoxication is not a substitute for intent. Trial courts must remember that the purpose of the McDaniel rule is to remove voluntary intoxication as a defense, not to provide an affirmative instruction for the state which might mislead a jury into thinking that it is not necessary to prove intent, when intent is a requisite ingredient of the offense."). But see supra note 204 (noting conflicting language in the same decision).

232 S.E.2d 328 (S.C. 1977).

${ }^{203}$ See id. at 330 ("We are asked to hold that voluntary intoxication is a defense to crimes requiring proof by the State of specific intent ....").

${ }^{209}$ Id. at $330-31$.

${ }^{210} I d$.

${ }^{211}$ Egelhoff, $116 \mathrm{~S}$. Ct. at 2024-25 (Ginsburg, J., concurring in the judgment) (citations omitted) (quoting Powell v. Texas, 392 U.S. 514, 545 (1968) (Black, J., concurring)). 
would vitiate the constitutional principles of separation of powers and the prohibition of ex post facto laws.

\section{THE OFFENSE OF INTOXICATED CRIMINAL CONDUCT}

This Comment does not question the valid interest states have in punishing intoxicated wrongdoers. The intuitive feeling that an offender's intoxication should not excuse his criminal conduct makes sense; after all, intoxicated wrongdoers are no less dangerous than sober offenders. Incapacitation alone might, therefore, justify punishing many intoxicated wrongdoers to the same extent as sober offenders. In addition, the high incidence of intoxication among violent offenders, ${ }^{212}$ while not necessarily proof of a causal relationship, probably justifies establishing special rules of criminal liability for intoxicated wrongdoers.

Part III of this Comment argued that prohibiting an intoxicated wrongdoer from introducing intoxication evidence to negate the mens rea of the charged offense violates due process. Part III also argued that evidentiary proscriptions should not be considered implicit redefinitions of a state's substantive criminal law. Moreover, I have maintained that an explicit redefinition of an offense to render intoxication evidence irrelevant to criminal liability would vitiate the morally compelling, though arguably non-constitutional, culpability requirement of the criminal law.

How might society constitutionally give effect to the sentiment expressed by the Mississippi prosecutor whose remark opened this Comment? The following two-part approach follows from the discussions above: (1) intoxication should be given full demonstrable exculpatory significance in negating any subjective mens rea element of a charged offense; and (2) separate offenses of intoxicated criminal conduct (e.g., homicide, endangerment, or destruction) should be enacted, each providing for a mens rea element of negligence. ${ }^{213}$

${ }^{212}$ See, e.g., William F. Wieczorek et al., Alcohol, Drugs and Murder: A Study of Convicted Homicide Offenders, 18 J. CRIM. JUST. 217, 220 (1990) (finding that 56\% of 1887 homicide offenders were under the influence of alcohol or drugs during the commission of their crimes); Richard M. Yarvis, Patterns of Substance Abuse and Intoxication Among Murderers, 22 BULL. AM. ACAD. PSYCHIATRY \& L. 133, 137 (1994) (finding that $48 \%$ of 100 convicted murderers were intoxicated during the commission of their crimes).

${ }^{213}$ This approach is not novel. Other commentators have suggested, for varying reasons, the creation of criminal negligence laws to be applied to intoxicated wrongdoers. See, e.g., FINGARETTE \& HASSE, supra note 75, at 103-04 (desiring a "broadening of criminal negligence"); THE LAW COMMISSION, CONSULTATION PAPER NO. 127: 
The first part of this proposed approach follows directly from the due process objections raised in Part III of this Comment. Neither evidentiary proscriptions nor implicit redefinitions of existing offenses satisfy the due process requirement that a defendant be allowed to introduce reliable exculpatory evidence in his defense. ${ }^{214}$ The first part of this approach admits for the jury's consideration all logically relevant evidence to determine whether or not the defendant is guilty of the crime charged. ${ }^{215}$ Although some commentators have argued that intoxication has less pharmacological relation to the formation of intent than is generally thought to be the case, ${ }^{216}$ such arguments are properly addressed to juries to rebut defendants' assertions of putatively exculpatory intoxication evidence. ${ }^{217}$ Until medical science definitively answers such questions, fairness requires that potentially exculpatory evidence not be excluded merely because the state wishes to make it easier to convict intoxicated wrongdoers.

If the skeptical commentators are correct in their assertion that intoxicated wrongdoers almost always intend, in a criminally culpable sense, their actions, admitting intoxication evidence should not change the result in many prosecutions. In Egelhoff, for example, the jury was persuaded that the State proved the requisite mens rea beyond a reasonable doubt by its presentation of a significant amount of evidence. ${ }^{218}$ Because proof of mens rea is always circumstantial and usually inferred from a range of evidence, one more piece of evidence-the defendant's intoxication-is not likely to be determinative. In those cases in which evidence of severe intoxication successfully raises a reasonable doubt as to mens rea, the defendant properly will be acquitted. Moreover, juries will be relieved in all cases from

INTOXICATION AND CRIMINAL LIABILITY 75-94 (1993) [hereinafter LAW COMMISSION REPORT] (proposing and explaining the offense of "criminal intoxication"). Because these and other commentators have explored this approach at some length, I will not duplicate their efforts here. Rather, I wish to show why this approach is the only permissible one given the due process concerns presented in this Comment.

214 See supra Part III.C.

215 See supra Part III.C.2.d.

${ }^{216}$ See supra note 75.

${ }^{217}$ A similar, though more skeptical, suggestion that use of "scientific data on intoxication" is a "second best approach" to justice, following minimal inclusion of medical testimony is made in Chester N. Mitchell, The Intoxicated Offender-Refuting the Legal and Medical Myths, 11 INT'L J.L. \& PSYCHIATRY 77, 100-03 (1988).

${ }^{218}$ See supra note 39 and accompanying text. 
the confusing and arbitrary task of considering intoxication evidence on the issue of actus reus but not of mens rea. ${ }^{29}$

The second part of the proposed approach aims to criminalize the conduct that might otherwise go unpunished in the prosecution of subjective mens rea offenses. Although a person might be not guilty of deliberate homicide because he lacked the requisite subjective mens rea due to severe intoxication, he may nevertheless be guilty of intoxicated homicide, which would require a mens rea of only negligence.

Creating a separate offense requiring a mens rea of negligence clearly distinguishes the two countervailing concerns that are at stake with intoxicated wrongdoers: that negligent offenders should not be punished as deliberate offenders, and that negligent offenders deserve some amount of punishment. This approach properly recognizes that, although subjective mens rea may be lacking, severely intoxicated wrongdoers are culpably negligent for voluntarily assuming a condition making criminal behavior more likely, and should be punished accordingly. This approach eschews the fiction of the negligent deliberate offender; it forces society to make criminalization judgments openly on the legislature's floor, subject to the ameliorative effects of political debate, rather than through the back door of implicit redefinitions, evidentiary proscriptions, judges' wisdom, or common law tradition.

The level of punishment for intoxicated criminal conduct certainly is a crucial issue. This Comment has argued that the legislature is the proper institution to determine offenders' criminal responsibility. Although negligence offenses typically carry a less severe punishment than deliberate offenses, ${ }^{220}$ it does not appear that the Eighth Amendment's prohibition of cruel and unusual punishments requires such treatment. ${ }^{221}$ The British Law Commission, in a report discussing the creation of a criminal intoxication offense similar to that proposed here, forcefully stated that it

${ }^{219}$ Montana law, for instance, allows intoxication evidence to be introduced on the issue of whether the defendant was capable of performing the actus reus of the offense charged. See Brief for Petitioner [State of Montana] at 9-10, Montana v. Egelhoff, 116 S. Ct. 2013 (1996) (No. 95-566).

${ }^{220}$ Compare 18 PA. CONS. STAT. ANN. $\$ \$ 106(\mathrm{~b})(6), 2504$ (providing a maximum sentence of five years' imprisonment for involuntary manslaughter), with id. § 1102 (providing a sentence of death or life imprisonment for first-degree murder).

${ }^{221}$ See Harmelin v. Michigan, 501 U.S. 957, 1001 (1991) ("The Eighth Amendment does not require strict proportionality between crime and sentence.") (Kennedy, J., concurring). 
regard[s] as unacceptable the suggestion that there should be the same maximum punishment for the intoxication offence as for [the applicable offense if the defendant had acted while sober].... Although the basis of the intoxication offence is that the defendant was at fault in becoming intoxicated in the first place, that fault is of a more general and less obviously culpable nature than the fault, the intentional or reckless commission of a defined criminal act, that founds liability for the [otherwise applicable offense]. It would not be right to put the two cases on the same level in respect of punishment.

Although other influential commentators have expressed similar convictions, ${ }^{223}$ criminalization judgments-within the due process constraints discussed above ${ }^{224}$-ultimately should be left to the legislative process. Requiring the legislature to face the criminalization question candidly may itself lead the legislature to differentiate the punishment of an intoxicated, negligent offender and a deliberate offender. If it does not, at least the intoxicated wrongdoer will be treated fairly, if harshly.

\section{CONCLUSION}

The Due Process Clause memorializes the social judgment that not every means to a permissible end is just. Intoxicated wrongdoers, like all criminal defendants, depend on that judgment to secure their right to a fair opportunity to defend against the state's criminal charges. If society holds intoxicated wrongdoers criminally liable to the same extent as sober offenders, it must do so in a manner that preserves defendants' right to introduce reliable, exculpatory intoxication évidence. To do otherwise reestablishes "retaliation and vengeance as the motivation for public prosecution." ${ }^{225}$

222 LAW COMMISSION REPORT, supra note 213, at 81.

${ }^{223}$ See, e.g., Hall, supra note 75, at 1061 ("The solid, unavoidable fact, was that a harm committed under gross intoxication ought to be clearly distinguished from a like injury by a sober person.").

${ }^{224}$ See supra Part III.C.1.

${ }^{225}$ Morissette v. United States, 342 U.S. 246, 251 (1952). 
